Review

\title{
үठ T Cells and Their Potential for Immunotherapy
}

\author{
Yan-Ling Wu ${ }^{1}$, Yan-Ping Ding ${ }^{1,2}$, Yoshimasa Tanaka ${ }^{3}$, Li-Wen Shen², Chuan-He Wei², Nagahiro Minato ${ }^{4}$, \\ and Wen Zhang ${ }^{\circledR}$ \\ 1. Lab of Molecular Immunology, Zhejiang Provincial Center for Disease Control and Prevention, 630 Xincheng Road, Hangzhou, 310051, China \\ 2. Lab of Chemical Biology and Molecular Drug Design, College of Pharmaceutical Science, Zhejiang University of Technology, 18 Chaowang Road, \\ Hangzhou, 310014, China \\ 3. Center for Innovation in Immunoregulative Technology and Therapeutics, Graduate School of Medicine, Kyoto University, Kyoto, 606-8501, \\ Japan \\ 4. Department of Immunology and Cell Biology, Graduate School of Medicine, Kyoto University, Kyoto, 606-8501, Japan
}

\begin{abstract}
$\triangle$ Corresponding authors: Yanling Wu, Lab of Molecular Immunology, Zhejiang Provincial Center for Disease Control and Prevention, 630 Xincheng Road, Hangzhou, 310051, China; Tel: +86-571-87115282; Fax: +86-571-87115282; e-mail: ylwu@cdc.zj.cn; Wen Zhang, Lab of Chemical Biology and Molecular Drug Design, College of Pharmaceutical Science, Zhejiang University of Technology, 18 Chaowang Road, Hangzhou, 310014, China; Tel: +86-571-88871507; Fax: +86-571-88871507; e-mail: wzhang63@zjut.edu.cn.

(c) Ivyspring International Publisher. This is an open-access article distributed under the terms of the Creative Commons License (http://creativecommons.org/ licenses/by-nc-nd/3.0/). Reproduction is permitted for personal, noncommercial use, provided that the article is in whole, unmodified, and properly cited.
\end{abstract}

Received: 2013.10.04; Accepted: 2013.12.17; Published: 2014.01.10

\begin{abstract}
Vү9Vס2 (also termed $V y 2 V \delta 2) T$ cells, a major human peripheral blood $y \delta$ T cell subset, recognize microbial (E)-4-hydroxy-3-methylbut-2-enyl diphosphate and endogenous isopentenyl diphosphate in a TCR-dependent manner. The recognition does not require specific accessory cells, antigen uptake, antigen processing, or MHC class I, class II, or class Ib expression. This subset of T cells plays important roles in mediating innate immunity against a wide variety of infections and displays potent and broad cytotoxic activity against human tumor cells. Because $ү \delta T$ cells express both natural killer receptors such as NKG2D and $\gamma \delta T$ cell receptors, they are considered to represent a link between innate and adaptive immunity. In addition, activated $y \delta$ T cells express a high level of antigen-presenting cell-related molecules and can present peptide antigens derived from destructed cells to $\alpha \beta$ T cells. Utilizing these antimicrobial and anti-tumor properties of $\gamma \delta T$ cells, preclinical and clinical trials have been conducted to develop novel immunotherapies for infections and malignancies. Here, we review the immunological properties of $y \delta$ T cells including the underlying recognition mechanism of nonpeptitde antigens and summarize the results of $y \delta T$ cell-based therapies so far performed. Based on the results of the reported trials, $\gamma \delta$ T cells appear to be a promising tool for novel immunotherapies against certain types of diseases.
\end{abstract}

Key words: $\gamma \delta \mathrm{T}$ cells, nonpeptide antigen, tumor, infection, autoimmune and allergic diseases, immunotherapy

\section{Introduction}

$\mathrm{T}$ cells are subdivided into two major populations distinguished by their surface expression of $\alpha \beta$ and $\gamma \delta$ T cell receptors (TCR). Both $\alpha \beta$ and $\gamma \delta$ T cells arise from common multipotent double negative (DN) precursors in the thymus, which can be further separated into four DN subsets based on CD44 and CD25 expression $[1,2]$. The $T$ cells undergo extensive DNA rearrangements at the $\beta, \gamma$ and $\delta$ TCR loci aiming to express functional TCR chains and make a selection between two developmental programs during the
DN3 stage, thus generating two distinct characteristics and functions of T cell subsets [3, 4]. Cells with the $\alpha \beta$ TCR generally express CD4 or CD8 lineage markers and mostly fall into helper or cytotoxic/effector subsets, whereas, cells with the $\gamma \delta$ TCR in humans usually do not express the lineage markers. They do not require conventional antigen presentation in the context of MHC [5]. In fact, the $\alpha \beta$ and $\gamma \delta \mathrm{T}$ cell populations recognize different types of antigens. $\alpha \beta T$ cells recognize non-self peptide fragments restricted 
by MHC molecules. $\gamma \delta \mathrm{T}$ cells, on the other hand, recognize unconventional antigens including stress molecules like MICA and MICB and non-peptidic metabolites of isoprenoid biosynthesis [6-9] and so on. Ligand recognition by $\gamma \delta \mathrm{T}$ cells appears to be dispensable for the selection of $\gamma \delta \mathrm{T}$ cells in the adult thymus [10].

Human $\gamma \delta$ T cells can be divided into three main populations based on $\delta$ chain expression. $\gamma \delta \mathrm{T}$ cells expressing V $\delta 1$ chains are prominent in the intraepithelial layer of mucosal surfaces, where they are involved in maintaining epithelial tissue integrity when facing damage, infection, or transformation [11], responding to stress antigens on epithelial cells [12] and producing IL-10 but little or no IL-2, IL-4 or IFN- $\gamma$ [13]. They also appear in the peripheral blood, but the intraepithelial and blood populations seem to mix little or not at all $[14,15]$. The second population of $\gamma \delta$ $\mathrm{T}$ cells expresses $\mathrm{V} \delta 2$ chain products and represents the majority of circulating $\gamma \delta \mathrm{T}$ lymphocytes in healthy human adults, comprising up to $50 \%-90 \%$ of the peripheral $\gamma \delta \mathrm{T}$-cell population. The V 22 chain pairs almost exclusively with $\mathrm{V}_{\gamma} 9$ (also termed $\mathrm{V}_{\gamma} 2$ ). The $\mathrm{V} \gamma 9 \mathrm{~V} \delta 2$ pairing is present only in humans and nonhuman primates [16]. One attractive feature of Vס2 T cells is that they can serve as professional antigen-presenting cells (APCs) [17]. Activated Vס2 T cells acquire characteristics of professional APC, such as the expression of antigen presenting, costimulatory, and adhesion molecules, including MHC-II, CD80, and CD86 [18]. It is worthy of note that rapamycin or IL-18 treatment is reported to increase the expression of MHC-II, CD80, and CD86 on V82 T cell lines [18]. The third population is V $\delta 3 \mathrm{~T}$ cells, which take up about $0.2 \%$ of circulating $\mathrm{T}$ cells including $\mathrm{CD}^{+}$, $\mathrm{CD}^{+}$, and CD4-CD8- subsets. They are expressed CD56, CD161, HLA-DR, and NKG2D but without NKG2A and NKG2C [19]. The V83 T cells are found only a little in blood but are rich in liver and in patients with leukemias and some chronic viral infections. Through mitogen stimulation with IL-2, V83 T cells were expanded to recognize CD1d. Once activation, they can kill CD1d ${ }^{+}$target cells, release cytokines such as Th1, Th2, and Th17, and induce maturation of dendritic cells (DCs) into APCs [19].

\section{Y $\delta \mathrm{T}$ cell receptor}

Since the discovery of $\gamma \delta \mathrm{T}$ cells more than twenty five years ago, many articles have been published to address the physiological functions of these lymphocytes in animals and humans. These studies have emphasized a marked molecular, phenotypic, and functional heterogeneity of $\gamma \delta \mathrm{T}$ cells. $\gamma \delta \mathrm{T}$ cells account for $1-10 \%$ of $\mathrm{CD}^{+}$peripheral blood $\mathrm{T}$ lymphocytes of healthy adults [20] and the ratio of

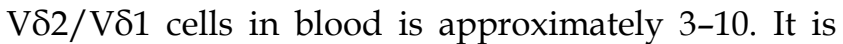
thus most likely that environmental or genetic factors control the balance of the subsets [21, 22]. Compen-

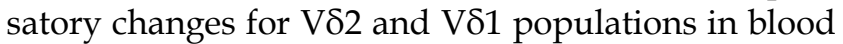
demonstrate a homeostatic balancing mechanism that controls the overall blood count [23]. Caccamo and colleagues showed the influence of gender and age on blood V82 levels, with women having lower levels, compared to age-matched men [24]. These studies suggest that V $\delta 2 \mathrm{~T}$ cell levels be controlled by multiple mechanisms, resulting in the difference in peripheral blood $\gamma \delta \mathrm{T}$ cell populations among people.

The crystal structure of a human $\mathrm{V} \gamma 9 \mathrm{~V} \delta 2 \gamma \delta \mathrm{TCR}$ [25] illustrates that the receptor shares similarities with the heavy and light chains of immunoglobulins, including the formation of a cleft between the CDR3 loops that is similar to the combining site of immunoglobulin. The amino acid residues consisting of the pocket are mostly germ-line-encoded. This strongly suggests that $\gamma \delta$ T cells directly recognize nonpeptide antigens, in a manner similar to antibodies. The recognition of phosphoantigens, however, requires cell-cell contact [26], which indicates that an as yet unidentified molecule(s) is also required to present phosphoantigens to $\gamma \delta$ TCR or to transduce the $\gamma \delta$ TCR mediated-signaling. Recent reports suggest that ATP synthase-F1/apolipoprotein A-1 complex and butyrophilin 3 are involved in the recognition of nonpeptide antigens by $\gamma \delta \mathrm{T}$ cells $[27,28]$.

It is difficult to identify antigens for $\gamma \delta \mathrm{T}$ cells other than phosphoantigens, because immunization, vaccination, or infection does not generally elicit antigen-specific $\gamma \delta \mathrm{T}$ cells. It is suggested that the $\gamma \delta$ TCR repertoire is directed against "self," most likely represented by inducible cell surface molecules that reflect the status of a cell or tissue [29]. Apart from $\gamma \delta$ TCR, $\gamma \delta$ cells express most T-lineage-specific genes, including cell surface receptors, signaling effectors, cytokines, and transcription factors, and they phenotypically and functionally resemble $\alpha \beta$ cells in both activated and resting states [30].

\section{Classification of $\mathrm{\gamma} \delta \mathrm{T}$ cells}

$\gamma \delta \mathrm{T}$ cells are distinguished from their $\alpha \beta \mathrm{T}$ cell counterparts by utilizing a distinct set of somatically rearranged variable $(\mathrm{V})$, diversity $(\mathrm{D})$, joining $(\mathrm{J})$, and constant $(\mathrm{C})$ genes. Compared to $\alpha \beta \mathrm{T}$ cells, available germ line repertoires of $\mathrm{V}_{Y}$ and $\mathrm{V} \delta$ genes are limited. $\gamma \delta \mathrm{T}$ cells contain fewer $\mathrm{V}, \mathrm{D}$, and J segments than $\alpha \beta$ $T$ cells. Regarding evolutionary forces that shape the $\mathrm{V}, \mathrm{D}$, and J gene segments, distinct forces were involved in the formation of the $\gamma$ and $\delta$ loci. In fact, the primate $\mathrm{V}_{\gamma}$ and $\mathrm{J} \delta$ genes are highly conserved, whereas, the $\gamma$-locus is split: the $\mathrm{V}_{\gamma} 9, \mathrm{~V}_{\gamma} 10$, and $\mathrm{V}_{\gamma} 11$ genes represent the conserved region of the $V_{\gamma}$ gene 
locus, but the remaining $\mathrm{V}_{\gamma}$ genes have been evolving rapidly [31].

According to different TCR $\gamma \delta$ chain expression, human $\gamma \delta \mathrm{T}$ cells can be classified into two subsets:

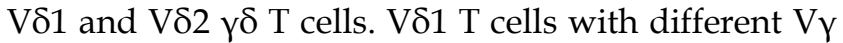
predominate in the intraepithelial subset of mucosal $\gamma \delta \mathrm{T}$ cells where the TCRs appear to recognize stress molecules on epithelial cells [32]. V82 T cells that generally coexpress $\mathrm{V}_{\gamma} 9$ are abundant in the peripheral blood and lymphatic system. Besides, they can also be classified into four subpopulations based on their expression of CD27 and CD45RA: naive $\left(\mathrm{CD}^{2} 7^{+} \mathrm{CD} 45 \mathrm{RA}^{+}\right)$, effector memory (CD27-CD45RA'), central memory $\left(\mathrm{CD}^{2} 7^{+} \mathrm{CD}^{2} 5 \mathrm{RA}^{-}\right)$and terminally differentiated (CD27-CD45RA ${ }^{+}$[33]. These subpopulations can exhibit unique functions during mycobacterial infection that correspond to the functions of their a $\beta$ T cell analogues [33].

Although the number of available $\mathrm{V} \delta$ genes is quite small, the combinatorial diversity of the $\gamma \delta$ TCR repertoire is at least as large as the $\alpha \beta$ TCR repertoire, owing to extensive non-genetically determined mechanisms: for example, $\mathrm{N}$ region insertions, imprecise joining, usage of three reading frames, and so on.

\section{Mechanism of ligand recognition}

$\gamma \delta \mathrm{T}$ cells can recognize a variety of structurally different ligands that vary much in size, composition and molecular structure, including non-peptidic antigens, MHC and non-MHC cell surface molecules, soluble proteins, sulfatide and so on.

\section{Non-peptidic antigens}

Pfeffer et al. [34, 35] suggested that non-peptide antigens may be important targets for T-cell recognition, which may occur for infections with fungus, bacteria, or protozoa. Porcelli et al. [36] demonstrated that monoalkyl phosphates (MEP) might stimulate $\gamma \delta$ $\mathrm{T}$ cells in a TCR-dependent manner which was similar to naturally occurring non-peptide mycobacterial antigens. The natural non-peptide antigens are usually fixed in their structure with less antigenic modulation and are much smaller, so the recognition of these antigens is more quickly and effectively with as fast as 2-3 minutes after exposure, indicating that it is not need for antigen uptake and processing. Studies also have confirmed that $\gamma \delta \mathrm{T}$ cells are specific to recognize phosphate-containing compounds with short, non-bulky carbon chains [37, 38]. Recognition of the prenyl pyrophosphates by the $\mathrm{V} \gamma 9 \mathrm{~V} \delta 2 \gamma \delta$ TCRs depends on all CDRs [39], as these small molecules are usually presented on the surface of target cells. These findings provide convincing evidence that human $\gamma \delta$ $\mathrm{T}$ cells can recognize a variety of small phosphory- lated non-peptide antigens.

Butyrophilin BTN3A1 has been identified as phosphorylated antigen-presenting molecule (APM) to $\mathrm{V} \gamma 9 \mathrm{~V} \delta 2 \mathrm{~T}$ cells [40], which belongs to a family of immunoglobulin-like molecules with immunomodulatory functions [28, 40,41]. It plays an important role in Vy9V82 TCR recognition of prenyl pyrophosphates. Researches have found that it seems function as a sensor for the intracellular levels of phosphorylated antigens, not the same as a costimulatory ligand or a classical presenting molecule binding prenyl pyrophosphates with its extracellular domains [42]. BTN3A1 molecules are modified via specifically binding with these antigens, thus leaving more free space to facilitate the binding of antigens [40]. The identification of BTN3A1 as an additional APM enriches the field of human immunological recognition, with potentially far-reaching implications for clinical immunotherapy.

\section{MHC molecules}

$\gamma \delta \mathrm{T}$ cells can recognize MHC molecules such as group 1(CD1a, b, c) and group 2 (CD1d) CD1 molecules $[43,44]$. The stress-induced MHC class I-related molecules MICA and MICB including a1 and a2 domains are also involved in the recognition by human $\gamma \delta \mathrm{T}$ cells, and do not need Ag processing [45]. Willcox et al. demonstrated a new kind of EPCR-dependent recognition of cytomegalovirus (CMV)-infected cells by $\gamma \delta \mathrm{T}$ cells [46]. They found that human $\gamma \delta$ TCR could directly bound endothelial protein $\mathrm{C}$ receptor (EPCR), which is a MHC-like molecule that binds lipids similar to the antigen-presenting molecule CD1d and can make $\gamma \delta \mathrm{T}$ cells recognize endothelial cells which are targets for cytomegalovirus infection and epithelial tumors. CMV infection can activate $\gamma \delta \mathrm{T}$ cells specific for self antigens inducing by a multimolecular stress signature on the surface of infected cells, containing EPCR and costimulatory ligand (s). The $\gamma \delta$ TCR bound EPCR in an antibody-like way, independently of lipids. Stress surveillance by $\gamma \delta \mathrm{T}$ cells may consist of innate-like (NKG2D-mediated) components and adaptive (TCR-specific) components, with the $\gamma \delta$ TCR engaging a stress-regulated self antigen.

\section{Soluble proteins}

Some soluble proteins are also involved in the recognition by $\gamma \delta \mathrm{T}$ cells, for example, bacterial proteins including the unrelated staphylococcal enterotoxinA (SEA) [47] and the toxin listeriolysin O (LLO) [48]. $\gamma \delta \mathrm{T}$ cells can also recognize heat shock proteins (HSPs), which does not need antigen processing and can occur in the absence of any APCs [49]. There is no substantial evidence demonstrating that HSP recog- 
nition involves the TCR. HSPs may signal through TLRs, directly or indirectly through binding peptides or hydrophobic ligands, such as LPS [50,51].

In addition, researches show that the myelin-derived glycosphingolipid sulfatide can also be recognized by human $\gamma \delta \mathrm{T}$ cells [52], indicating that there may also exist other kinds of non-peptidic Ags for $\gamma \delta \mathrm{T}$ cells which have not yet been identified.

NKG2D, which is expressed on $\mathrm{V} \gamma 9 \mathrm{~V} \delta 2 \mathrm{~T}$ cells, plays an important role in the ligand recognition by $\gamma \delta \mathrm{T}$ cells, and also is key molecular determinants for the $\mathrm{V} \gamma 9 \mathrm{~V} \delta 2 \mathrm{~T}$-cell recognition of various carcinomas $[53,54]$. NKG2D is a C-type lectin receptor, which provides activation signals by binding to its ligands such as MIC and ULBP families. NKG2D ligands are not expressed by most normal tissues but are upregulated by many tumor-cell types, which are required for tumor cell-recognition by $\mathrm{V} \gamma 9 \mathrm{~V} \delta 2 \mathrm{~T}$ cells.

The precise molecular mechanisms of ligand recognition by $\gamma \delta \mathrm{T}$ cells remain to be elusive: one supposing that the recognition of nonpeptide antigens by $\gamma \delta \mathrm{T}$ cells is essentially the same as that by immunoglobulins (Igs) [55], just binding to the specific ligand; the other one is the mechanism similar to that of a $\beta$ TCRs, involving a specific ligand and a self-identifying presenting molecule [56]. Binding studies exihibit the existence of Ig-like recognition and a crystallographic analysis supports the direct receptor-ligand interaction for proteinaceous antigens [57]. But further investigation has to be conducted to verify the underlying mechanism of the $\gamma \delta \mathrm{T}$ cell recognition of nonpeptide antigens, because third molecule may possibly be involved in the efficient recognition.

\section{Activation of $\mathrm{y} \delta \mathrm{T}$ cells}

Early studies demonstrated that most V $\gamma 9 \mathrm{~V} \delta 2 \mathrm{~T}$ cells are strongly activated by a variety of killed microorganisms including bacteria such as Mycobacterium tuberculosis [58] and parasites such as Plasmodium falciparum [59]. Later, antigens have been identified as (E)-4-hydroxy-3-methyl-but-2-enyl diphosphate (HMB-PP), an immediate upstream metabolite of isopentenyl diphosphate (IPP), so called phosphoantigens [60]. The phosphoantigens can specifically activate $\mathrm{V} \gamma 9 \mathrm{~V} \delta 2 \mathrm{~T}$ cell subset at pico- to nanomolar concentrations. The bacterial HMB-PP levels determine the magnitude of $\mathrm{V} \gamma 9 \mathrm{~V} \delta 2 \mathrm{~T}$ cell expansion in vitro or upon transfer of human PBMC and subsequent infection with bacteria. Analogues with potent and selective stimulatory activity for $\mathrm{V} \gamma 9 \mathrm{~V} \delta 2 \mathrm{~T}$ cells can be synthesized. For instance, bromohydrin diphosphate (BrHPP) is active at nanomolar concentrations [61].

In contrast to many bacteria and protozoas, human cells utilize the mevalonate pathway for isoprenoid and IPP biosynthesis [62, 63], which also activates $\mathrm{V} \gamma 9 \mathrm{~V} \delta 2 \mathrm{~T}$ cells in vitro following presentation by professional antigen-presenting cells or tumor cells [64, 65], but only at concentrations not achieved physiologically in non-transformed cells. However, certain tumors yield higher concentrations of IPP, which can be sensed by VY9V82 T cells [66, 67].

The intracellular levels of IPP can be manipulated by the therapeutically administered drugs. Nitrogen-containing bisphosphonates (N-BPs) such as pamidronate (Pam) and zoledronic acid ( $\mathrm{Zol})$, which are in clinical use for osteoporosis and hypercalcemia of malignancies, can enhance intracellular levels of IPP by the inhibition of farnesyl diphosphate synthase (FPPS) [68-70], contributing to the activation and expansion of human $\mathrm{V}_{\gamma} 9 \mathrm{~V} \delta 2 \mathrm{~T}$ cells (Fig. 1).

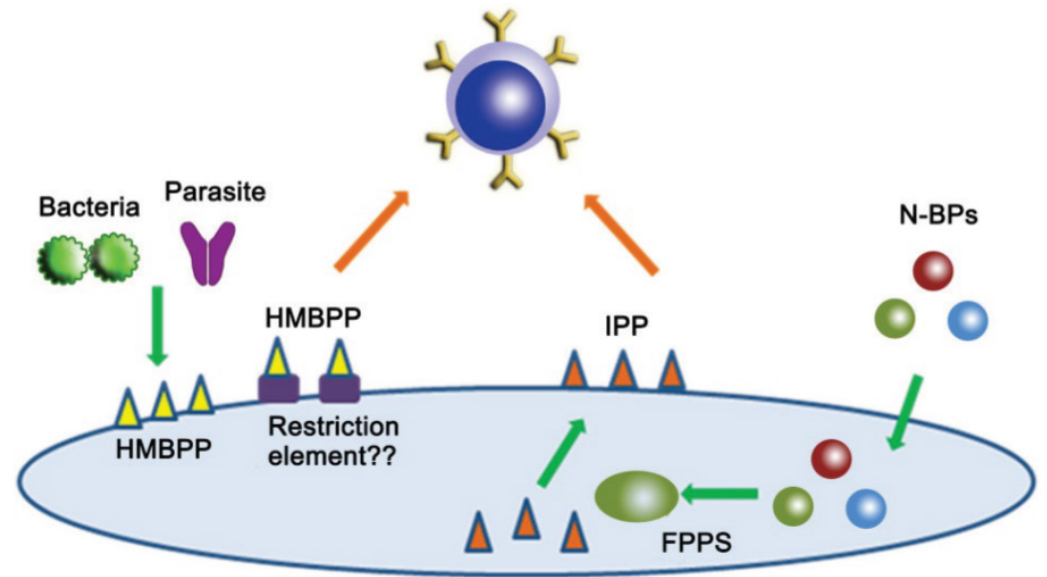

Figure I. Nonpeptide antigens for $y \delta$ T cell stimulation. 
Because the activation of $\gamma \delta \mathrm{T}$ cells does not require antigen processing or MHC molecules, but relies on cell-cell contact with APCs [71], stimulated $\gamma \delta$ $\mathrm{T}$ cells themselves seem to serve as APCs, but the self-activation or presentation is not effective, compared to the optimal stimulation by monocytes or tumor cells [72]. This indicates that TCR recognition of phosphoantigens requires antigen presentation molecules on APCs. In fact, tetramers of human $\gamma \delta$ TCRs bind to APCs in an antigen-dependent manner [73-75].

Recently, Harly and coworkers [27] made a significant advancement on the mechanism underlying the activation of human $\mathrm{V} \gamma 9 \mathrm{~V} \delta 2 \mathrm{~T}$ cells. They found that CD277, a member of butyrophilin molecules, played a central role during the $\gamma \delta \mathrm{T}$ cell activation. It is, however, still unclear how the Vy $9 \mathrm{~V} \delta 2 \mathrm{~T}$ cells recognize the phosphoantigen (or anti-CD277 $\mathrm{mAb}$ )-induced perturbation of the CD277 surface molecule [76]. The requirement of CD277 for the recognition may explain why human $\gamma \delta \mathrm{T}$ cells recognize phosphoantigens in a species-specifc manner, because there is no CD277 ortholog in rodents.

In addition, the activation of $\gamma \delta \mathrm{T}$ cells also requires a variety of costimulatory molecules, including immunoglobulin (Ig) superfamily coreceptors (like CD28 or JAML), tumor necrosis factor receptor (like CD27) and atypical costimulatory molecules such as NKG2D or CD46.

\section{Ig superfamily coreceptors}

Several functional assays have suggested CD28 plays an active role in $\gamma \delta \mathrm{T}$ cell activation [77, 78], which may produce both qualitative and quantitative changes resulting in lower activation threshold and enhanced T cell activity. Anti-CD28 agonist antibodies can enhance human $\gamma \delta \mathrm{T}$ cell proliferation [79], while blocking antibodies inhibit it obviously [80].

Junctional adhesion molecule-like protein (JAML) has been considered as a key co-receptor in mouse DETC (express an oligoclonal Vy5V81 TCR) activation [81], whose costimulation can induce DETC proliferation and the secretion of TNF- $\alpha$, IFN- $\gamma$ and IL-2. However, it remains unknown whether JAML plays any role in the costimulation of other (including human) $\gamma \delta \mathrm{T}$ cell subsets.

\section{Tumor necrosis factor receptor (TNFR)}

CD27, one of TNFR superfamily co-receptors, has also been shown important contributions to $\mathrm{T}$ cell activation. About $80 \%$ of $\mathrm{V} \gamma 9 \mathrm{~V} \delta 2 \mathrm{~T}$ cells express CD27 (TNFRSF7) [82]. Upon activation with PMA and ionomycin, most of $\mathrm{CD} 27^{+} \mathrm{V} \gamma 9 \mathrm{~V} \delta 2 \mathrm{~T}$ cells produce IFN- $\gamma$ with less than $1 \%$ is IL-17 [82]. The proliferation of $\mathrm{CD} 27^{+} \mathrm{V} \gamma 9 \mathrm{~V} \delta 2 \mathrm{~T}$ cells is sensitive to CD70-CD27 modulation, which provides survival and proliferative signals to control $\gamma \delta$ T-cell activation. CD27 signals can activate the non-canonical NF-kB pathway and enhance the expression of anti-apoptotic and cell cycle-related genes [83]. Besides, CD27 costimulation plays important roles in the protection from activation induced cell death (AICD) following phosphoantigen stimulation [82] and the expansion of tumour-specific cytotoxic T lymphocytes (CTLs) [84, 85].

\section{Atypical costimulatory molecules}

The C-type lectin-like NKG2D receptor plays critical roles in the activation of T cells. NKG2D shows costimulatory function in $\gamma \delta \mathrm{T}$ cells, which can enhance the response of $\mathrm{V} \gamma 9 \mathrm{~V} \delta 2 \mathrm{~T}$ cells upon TCR activation. NKG2D ligation in $\mathrm{V} \gamma 9 \mathrm{~V} \delta 2 \mathrm{~T}$ cells can upregulate the activation marker CD69 independently of TCR stimulation [48]. NKG2D can either directly activate $\mathrm{T}$ cells, as happens for NK cells, or act as a co-receptor to the TCR just as $\mathrm{CD}^{+} \mathrm{T}$ cells do [82]. Upon activation, these NKG2D-expressing $\mathrm{T}$ cells can kill tumor [86] or pathogen-infected cells [87].

Furthermore, $\mathrm{V} \gamma 9 \mathrm{~V} \delta 2 \mathrm{~T}$ cells express the $\mathrm{BC} 2$ isoform of CD46, which can reduce TNF- $\alpha$ and IFN- $\gamma$ secretion in HMBPP-stimulated $\mathrm{V} \gamma 9 \mathrm{~V} \delta 2 \mathrm{~T}$ cell cultures [88] when signaling through this isoform, indicating a novel role for CD46 in regulating the production of (Th1-like) pro-inflammatory cytokines in human $\gamma \delta \mathrm{T}$ cells.

\section{Functions of $y \delta \mathrm{T}$ cells}

$\gamma \delta \mathrm{T}$ cells display a variety of functions. They can produce different kinds of cytokines and chemokines such as interferon- $\gamma$ (IFN- $\gamma)$ and tumor necrosis factor- $\mathrm{a}$ (TNF-a), and growth factors such as IGF-1. Besides, they can regulate immune responses via interactions with other cells, for example, they can provide help for B cells and present antigens for $\alpha \beta \mathrm{T}$ cells. Other important roles are involved in the macrophage recruitment, cytolytic activity and so on. Such main functions are detailed below.

Firstly, $\gamma \delta \mathrm{T}$ cells can produce a vast variety of cytokines and chemokines to regulate other immune (e.g., Tregs) and non-immune cells. The types and physiological roles of these cytokines, chemokines and others are in detail discussed in the part of the subtitle "Cytokine secretion".

Secondly, they can provide help for B cells [89]. Caccamo group found that a subset of $\mathrm{V} \gamma 9 \mathrm{~V} \delta 2^{+} \mathrm{T}$ cells that expresses CXC-chemokine receptor 5 (CXCR5) which defines follicular B $\mathrm{Th}\left(\mathrm{Th}_{\mathrm{f}}\right)$ cells were able to induce significant production of Igs even in the absence of $\mathrm{Ag}$, and provided help for naive $\mathrm{B}$ cells to produce IgM, IgG, and IgA Abs, suggesting that they are highly efficient at providing $B$ cell help and play a 
significant regulatory role in humoral immunity [90].

Thirdly, $\gamma \delta \mathrm{T}$ cells can trigger dendritic cell (DC) maturation. Vү9V82 lymphocytes can induce full activation of immature dendritic cells (iDCs) infected with pathogens, such as Mycobacterium bovis bacillus Calmette-Gue'rin (BCG) [91]. Human $\gamma \delta \mathrm{T}$ cells induced DC maturation [92] via TCR-CD1 [93] and Fas-FasL interactions [94]. Because DCs are uniquely resistant to Fas-induced cell death, Fas-FasL interaction can transduce maturation signaling. When human $\mathrm{V} \gamma 9 \mathrm{~V} \delta 2 \mathrm{~T}$ cells were co-cultured with iDCs, they induced increased expression of CD86 and MHC class I on iDCs [95], mainly via $\gamma \delta$ T cell-derived TNF- $\alpha$ and IFN- $\gamma$. DC maturation induced by LPS was further enhanced by $\gamma \delta$ T cells [96].

Fourthly, $\gamma \delta \mathrm{T}$ cells are involved in the macrophage recruitment. In listeriosis, $\gamma \delta \mathrm{T}$ cells seem to control the production of macrophage chemoattractant protein I, because it was absent in mice genetically deficient in $\gamma \delta \mathrm{T}$ cells [97]. A recent investigation of wound healing demonstrated that epidermal $\gamma \delta \mathrm{T}$ cells could regulate keratinocyte proliferation after wounding [98], and induce hyaluronan production by the epithelial cells [99]. During the subsequent tissue repairing processes, hyaluronan is deposited in the extracellular matrix where it becomes involved in the recruitment of macrophages to the wound lesions. In addition, $\gamma \delta \mathrm{T}$ cells facilitate cellular differentiation of monocytes and macrophage lineage cells [100], as monocytes differentiate into inflammatory macrophages during bacterial infections, but fail to undergo maturation when $\gamma \delta \mathrm{T}$ cells are absent.

Fifthly, $\gamma \delta \mathrm{T}$ cells exhibit varying degrees of cytolytic activity to various kinds of malignancies, such as neuroblastomas [101-103]. Chargui et al. [104] suggested that the expanded $\gamma \delta \mathrm{T}$ cells which were derived from neuroblastoma patients effectively lysed autologous and allogeneic neuroblastoma cells, and zoledronate or BrHPP could increase the susceptibility of neuroblastoma cells to $\gamma \delta \mathrm{T}$ cells. The cytolytic activity of $\gamma \delta$ T cells could be induced through appropriate cellular contact $[105,106]$ and augmented by exposure to cytokines during ex vivo expansion, for example, IL-15 and/ or IL-18 [68, 107]. So ex vivo expanded $\gamma \delta \mathrm{T}$ cells can function as a promising tool for anti-malignancy immunotherapy.

Sixthly, $\gamma \delta \mathrm{T}$ cells produce growth factors that maintain epidermal integrity [98]. $\gamma \delta \mathrm{T}$ cells in Psoriasis, an immune mediated disease associated with hyperproliferation of keratinocytes and angiogenesis, have been showed to produce growth factors such as IGF-1, VEGF and FGF-2[108]. They can up-regulate IGF-1 production when stimulated with HMB-PP or
PMA/Ionomycin, and produce low amounts of VEGF $(<100 \mathrm{pg} / \mathrm{ml})$ and FGF-2 $(<15 \mathrm{pg} / \mathrm{mL})$ upon activation.

Seventhly, they can present antigens for $\alpha \beta T$ cells. It was reported by Brandes et al. that $\mathrm{V} \delta 2^{+} \mathrm{T}$ cells showed principal characteristics of professional antigen-presenting cells such as dendritic cells. After activation, these cells can rapidly express CC-chemokine receptor 7 (CCR7), which drives their migration to lymph nodes, and upregulate their expression levels of MHC class I and class II molecules and the co-stimulators CD80 and CD86 [109]. They can efficiently process antigens and provide co-stimulatory signals which can strongly induce naive $\alpha \beta$ T cell proliferation and differentiation. Human $\mathrm{V} \gamma 9 \mathrm{~V} \delta 2^{+} \mathrm{T}$ cells can also present antigens to $\mathrm{CD}^{+} \mathrm{T}$ cells and cross-present antigens to $\mathrm{CD}^{+} \mathrm{T}$ cells [109].

\section{Cytokine secretion}

Activated $\gamma \delta \mathrm{T}$ cells exhibit broad cytotoxic activity against a wide variety of tumor cells, in which they utilize death receptor/ligand (e.g. Fas/Fas-ligand)-dependent and perforin/granzymeor granulysin-dependent pathways. $\gamma \delta \mathrm{T}$ cells secrete various cytokines [110] and chemokines including proinflammatory Th1-like cytokines such as IFN- $\gamma$ and TNF- $\alpha$, and contribute to reduced survival of autologous tumor cells [111]. Besides, they also produce Th2 cytokines such as IL-4 in the bronchoalveolar lavage fluid of patients with allergic asthma [112, 113].

Furthermore, some $\gamma \delta$ T cells give rise to particular cytokines such as keratinocyte growth factor and connective tissue growth factor (CTGF), showing important functions in the control of epithelial integrity, fibrinogenesis and wound repair. Other $\gamma \delta \mathrm{T}$ cells also produce antimicrobial peptides such as cathelicidin/LL37, indicating the capacity in the local epithelial defense.

In addition, $\gamma \delta \mathrm{T}$ cells have been reported to secrete interleukin-10 (IL-10) [114], controlling CD8 ${ }^{+} \mathrm{T}$ cell expansion and regulating TNF-a secretion by activated CD8 ${ }^{+} \mathrm{T}$ cells, and IL-17 [115], regulating the expansion and recruitment of neutrophils and monocytes to initiate inflammatory responses. The role of IL-17-producing $\gamma \delta \mathrm{T}$ cells has been evaluated in various models of infection [116] and autoimmunity. Secretion of multiple cytokines and chemokines by activated $\gamma \delta$ cells and their physiological roles are shown in Fig. 2 


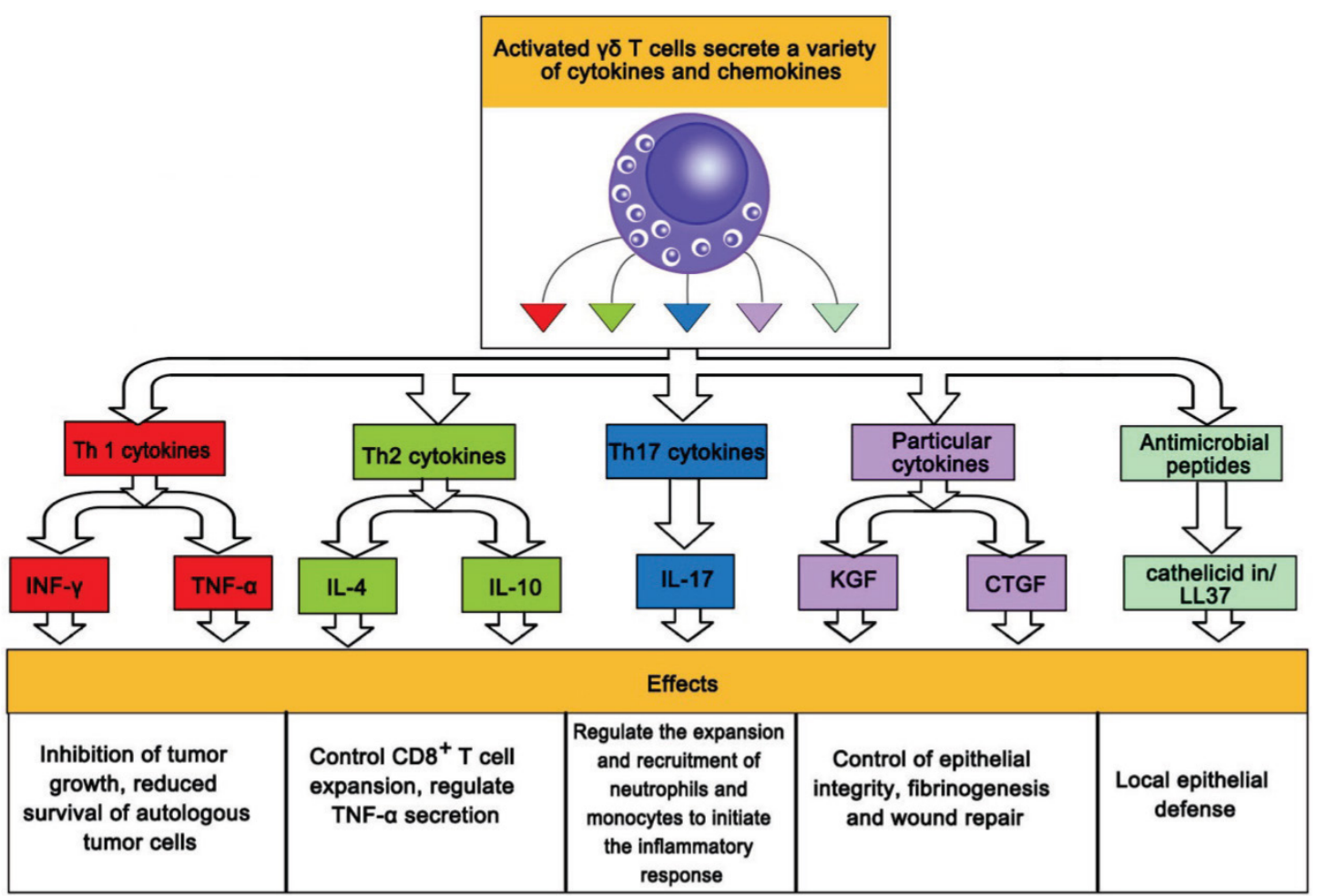

Figure 2. Secretion by activated $y \delta$ cells of multiple cytokines and their physiological roles.

\section{Applications}

\section{Y $\delta$ T-cell based cancer immunotherapy}

In 1890, Paul Ehrlich proposed vaccines against cancer, which was the first suggestion using the immune system to cope with cancer. In fact, immune deficiency states, such as iatrogenic immune suppression, common variable immunodeficiency (CVID), severe combined immunodeficiency (SCID), and acquired immunodeficiency syndrome (AIDS), make patients more susceptible to various kinds of malignancies $[117,118]$. The importance of immune surveillance against tumor emergence and progression was reinforced with the observation of different immune deficiency states. Targeting the immune system to combat tumors is a promising therapeutic strategy [119] although progress has been slow and success is limited.

Immunotherapeutic approaches for anti-tumor responses via stimulating the adaptive immune system rely on major histocompatibility complex (MHC)-restricted $\alpha \beta \mathrm{T}$ cells. Although significant advances in the adaptive immunotherapies toward tumors have been made and vaccine-based strategies have been improved, a $\beta$ T cell-mediated immunotherapies have met with limited success. Durable responses are scarce, and active immunotherapy has not achieved an established treatment modality. $\alpha \beta$ T cells require specific tumor-associated antigens (TAAs) and suitable costimulatory molecules for activation. Once failure or loss of TAAs, MHC molecules, and/or costimulatory molecules occurs, it will render tumor cells less susceptible to $\alpha \beta$ T-cell-mediated cytotoxicity or induce anergy in specific $\alpha \beta$ T cells.

$\gamma \delta \mathrm{T}$ cells are considered to be a member of innate immune cells and exhibit an important role in immune-surveillance and immune defense against tumors, including melanomas [120], leukemias, lymphomas, neuroblastomas, and other types of carcinomas $[102,104,121]$. The antitumor activity of $\gamma \delta \mathrm{T}$ cells has been confirmed by expanding them ex vivo followed by infusion to cancer patients [122, 123]. Recently, in vitro-activated $\gamma \delta \mathrm{T}$ cells have been shown to target a small number of colon cancer stem cells, which had been demonstrated to be attributable to the failure of conventional therapies. In addition, $\gamma \delta \mathrm{T}$ cells can kill chemotherapy (imatinib)-resistant chronic myelogenous leukemia lines.

$\gamma \delta \mathrm{T}$ cells can be utilized for antitumor therapies in an unconventional manner [64], because they exhibit a potent MHC-unrestricted lytic activity against a wide variety of tumor cells in vitro. In clinical studies, $\gamma \delta \mathrm{T}$ cells have been shown to infiltrate into different kinds of tumors, including lung carcinomas [124], renal cell carcinomas [125], and breast carcinomas [126]. It is worthy of note that they have exhibited to specifically respond in vitro to tumors but not to normal cells. Moreover, a high level of $\gamma \delta \mathrm{T}$ cells was found in disease-free survivors of acute leukemia 
following allogeneic bone marrow transplantation [127]. Clinical evidence in the therapy of human malignancies using $\gamma \delta \mathrm{T}$ cells stimulated with phosphoantigens or bisphosphonates [128] will further support the antitumor effects of this cell population in vivo.

Human $\gamma \delta$ T cells mediate anti-tumor immunity via several distinct pathways, such as the secretion of proinflammatory cytokines and pro-apoptotic molecules, and cell to cell contact-dependent lysis through an NK-like pathway or a TCR-dependent pathway [129]. Activated $\gamma \delta \mathrm{T}$ cells secrete large amounts of cytokines, which act on tumor cells or their microenvironment [130]. IFN- $\gamma$, a major cytokine secreted by activated $\gamma \delta \mathrm{T}$ cells, has multiple anti-tumor effects including direct inhibition of tumor growth, blocking angiogenesis, or stimulation of macrophages. IFN- $\gamma$, therefore, is a crucial cytokine in the $\gamma \delta \mathrm{T}$ cell-mediated anti-tumor responses.

Many reports demonstrate that $\gamma \delta \mathrm{T}$ cell clones derived from either tumor sites or blood of cancer patients exhibit potent cytotoxicity against tumor cells ex vivo [20]. In addition, $\gamma \delta \mathrm{T}$ cells have a unique capacity to present antigens to both CD8 and CD4 cells and potentially elicit strong adaptive anti-tumor responses [131]. Furthermore, $\gamma \delta \mathrm{T}$ cells can respond to stress stimuli originated from transformed cells and exhibit MHC-unrestricted antigen recognition. Activated $\gamma \delta \mathrm{T}$ cells can exert an immediate and robust direct cytotoxic effect, and simultaneously induce secondary inflammation which attracts tumor specific effector T cells [132]. Adoptive transfer of large number of activated $\gamma \delta \mathrm{T}$ cells, either alone or along with $\mathrm{CD}^{+}$tumor specific $\mathrm{T}$ cells, therefore, can potentially boost the dysfunctional host immune system in many ways.

Several clinical trials including patients with advanced diseases refractory to conventional treatments have been performed to test the safety and efficacy of $\gamma \delta$ T-cell-based immunotherapy. Consequently, up to $50 \%$ efficacy has been observed in a most recent clinical trial using phosphostim ${ }^{\mathrm{TM}}$ for expanding the autologous $\gamma \delta \mathrm{T}$ cells in patients with metastatic renal cell carcinomas [133].

Dokouhaki and his colleagues [134] have built a xenograft model of human non-small cell lung cancer (NSCLC) to study the in vivo function of $\gamma \delta \mathrm{T}$ cells, and found that the lung cancer progression was remarkably inhibited after the infusion of $\gamma \delta \mathrm{T}$ cells in the absence of cytokine co-administration. The results indicate that the interaction between NKG2D and its ligand (s) may partially contribute to the anti-tumor effect of human $\gamma \delta \mathrm{T}$ cells. Treatment with expanded and activated $\gamma \delta \mathrm{T}$ cells for NSCLC is especially promising. Firstly, $\gamma \delta \mathrm{T}$ cells reside in lung tissues and the number is increased in patients with NSCLC. Secondly, $\gamma \delta \mathrm{T}$ cells can recognize NSCLC cells in spite of the loss of HLA expression found in $69 \%$ of the cases. Thirdly, infusion of ex vivo expanded $\gamma \delta \mathrm{T}$ cells is feasible in patients with NSCLC [135].

To examine the anti-tumor activity of $\gamma \delta \mathrm{T}$ cells in breast cancer, a phase I trial was conducted, in which Zol and low-dose IL-2 were administered to 10 advanced metastatic breast cancer patients who were therapeutically terminal [136]. The results suggest that the treatment was well tolerated and promoted the effector maturation of $\mathrm{V} \gamma 9 \mathrm{~V} \delta 2 \mathrm{~T}$ cells in all patients. It is noteworthy that there was a statistically significant linkage between clinical outcome and the number of peripheral $\mathrm{V} \gamma 9 \mathrm{~V} \delta 2 \mathrm{~T}$ cells, as seven patients who failed to sustain $\mathrm{V} \gamma 9 \mathrm{~V} \delta 2 \mathrm{~T}$ cells showed progressive clinical deterioration, while three patients who sustained robust peripheral $\mathrm{V} \gamma 9 \mathrm{~V} \delta 2$ cell populations displayed one instance of partial remission and two of stable disease, respectively. Consistent with the earlier clinical trial in prostate cancer, there was a strong correlation of Vy9V82 $\mathrm{T}$ cell status with reduced carcinoma progression, and Zol plus low-dose IL-2 provided a novel, safe, and feasible strategy to treat refractory patients with advanced breast cancer [136]. It has been reported that the treatment of patients with Vy9V82 T cells plus Zol could efficiently enhance the lysis of MCF-7 breast tumor cells and PC-3 prostate carcinoma cells in a $\gamma \delta$ TCR-dependent manner at the effector to target ratios of 30:1 to 7.5:1 [126].

Recently, Kobayashi and his colleagues have reported a complete remission (CR) in a patient with advanced renal cell carcinomas who underwent 6 monthly cycles of autologous $\gamma \delta \mathrm{T}$ cell therapy, in which the activation and expansion of $\gamma \delta \mathrm{T}$ cells were performed in vitro using 2-methyl-3-butenyl diphosphate plus IL-2, followed by the infusion of the expanded $\gamma \delta \mathrm{T}$ cells, Zol (4 mg) plus low-dose IL-2 $\left(1.4 \times 10^{6} \mathrm{IU}\right)$ [137]. The clinical responses were associated with a sharp increase in the number of IFN- $\gamma$-producing adoptively transferred $\mathrm{V} \gamma 9 \mathrm{~V} \delta 2 \mathrm{~T}$ cells. The CR patient has been disease free for more than 3 years without any additional treatment. Some important clinical trials on $\gamma \delta \mathrm{T}$-cell-based cancer immunotherapy are summarized in Table 1. 
Table I. Examples of the important clinical assays about $ү \delta$ T-cell-based cancer immunotherapy.

\begin{tabular}{|c|c|c|c|}
\hline $\begin{array}{l}\text { Cancer } \\
\text { Immunotherapy }\end{array}$ & Cancer Type & Results & Ref. \\
\hline $\begin{array}{l}\text { Treated with } \\
\text { zoledronate+IL-2 }\end{array}$ & Malignant melanomas & 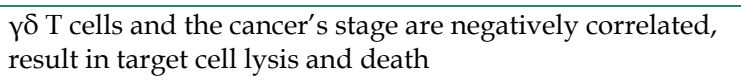 & [120] \\
\hline $\begin{array}{l}\text { Treated with } \\
\text { zoledronate+IL-2 }\end{array}$ & $\begin{array}{l}\text { Hormone-refractory prostate } \\
\text { cancer }\end{array}$ & $\begin{array}{l}\text { Partial remission and stable disease, aggregate increases in } \\
\gamma \delta \text { T cell numbers }\end{array}$ & {$[66]$} \\
\hline $\begin{array}{l}\text { Pretreated with pamidronate } \\
\text { and zoledronate }\end{array}$ & MCF-7 breast tumor & $\begin{array}{l}\text { Tumor cells were efficiently lysed, depended on the per- } \\
\text { forin-granzyme pathway. }\end{array}$ & [126] \\
\hline $\begin{array}{l}\text { Bone marrow grafts } \\
\text { depleted of } \alpha \beta \text { T cells }\end{array}$ & $\begin{array}{l}\text { Acute lymphoblastic leukemia } \\
\text { (ALL), Acute myeloid leukemia } \\
\text { (AML) }\end{array}$ & $\begin{array}{l}\text { Have a significant improvement in disease-free survival, a } \\
\text { post-BMT absolute increase in } \gamma \delta \mathrm{T} \text { cells was significantly } \\
\text { associated with } \alpha \beta \text { T-cell depletion. }\end{array}$ & [127] \\
\hline $\begin{array}{l}\text { Autologous } \gamma \delta \text { T cells infusion alone } \\
\text { or with IL-2 }\end{array}$ & Renal cell carcinoma (metastatic) & $\begin{array}{l}\text { The maximum-tolerated dose and safety of } \gamma \delta \text { T cells is } \\
8 \times 10^{9} \text { cells. }\end{array}$ & [128] \\
\hline Inoculation without cytokines & Non-small cell lung cancer & Progression is remarkablely inhibited. & [134] \\
\hline $\begin{array}{l}\text { In vitro proliferation of } \\
\gamma \delta \mathrm{T} \text { cells with pamidronate/IL-2 }\end{array}$ & $\begin{array}{l}\text { Non-Hodgkin lymphoma (re- } \\
\text { lapsed and/or refractory) or } \\
\text { multiple myeloma }\end{array}$ & $\begin{array}{l}\text { Pamidronate/IL- } 2 \text { was well tolerated, and no dose-limiting } \\
\text { toxicity was observed. }\end{array}$ & {$[138]$} \\
\hline Autologous $\gamma \delta \mathrm{T}$ cells & Colon carcinoma & $\begin{array}{l}\text { Recognition and efficient killing of autologous and alloge- } \\
\text { neic CCCL (Colon Carcinoma Cell Lines) }\end{array}$ & [139] \\
\hline Treated with zoledronic acid & Pancreatic carcinoma & $\begin{array}{l}\text { Tumor cells treated with zoledronic acid are more vulner- } \\
\text { able against } \gamma \delta \text { T cell attack. }\end{array}$ & [140] \\
\hline
\end{tabular}

\section{Applications of $\gamma \delta \mathrm{T}$ cells to treatment of patients with infectious diseases}

Infectious diseases are a serious threat to human health and gradually increase in global morbidity and mortality in recent years. Current strategies to control infections mainly focus on the pathogens themselves, but neglect the host factors which may regulate the progression of the diseases. The frequent appearance of drug resistance in infectious pathogens often leads to costly but ineffective therapy. In addition, the efficiency of vaccines inducing adaptive immune responses could be impaired by the rapid immune evasion of pathogens through their frequent mutations. In conclusion, innate immune cells that recognize the conserved structural components of pathogens and elicit rapid responses against infections have great potential in anti-infection immunotherapy.

Human $\gamma \delta \mathrm{T}$ cells are vital components of the innate immune system and play important roles in the early responses to invasive pathogens. Besides, some $\gamma \delta \mathrm{T}$ cells, such as IL-17-producing $\gamma \delta \mathrm{T}$ cells, have been demonstrated to be involved in the pathogenesis of transplantation rejection, autoimmune disease [141], inflammatory diseases [142] and allergy [143] in humans. The quality and quantity of human $\gamma \delta \mathrm{T}$ cells with dynamic variation affects the initiation, progression and prognosis of infectious diseases.

\section{Viral infections}

Although the mechanism underlying $\gamma \delta \mathrm{T}$ cell-mediated immune responses against viruses remains to be delineated, their protective roles have been confirmed in some acute and chronic viral infec- tions. The activation and cytokine secretions of $\gamma \delta \mathrm{T}$ cells are considered as indicators of early viral infection.

Recently, the beneficial effects of human Vү9V82 $\mathrm{T}$ cells against influenza virus infection have been re-ported. Vy9V82 $\mathrm{T}$ cells can control infection of several strains of influenza viruses, such as pandemic H1N1, human seasonal H1N1, and the avian H5N1 and H9N2 viruses [144]. A study has suggested that Vy9V82 T cells expressed both type 1 cytokines and chemokine receptors during influenza virus infection, and IPP-activated cells had a higher capacity to produce IFN-Y [145]. It is worth noting that IPP-activated $\gamma \delta \mathrm{T}$ cells also can inhibit seasonal and pandemic H1N1 viruses in a noncytolytic manner, mainly through IFN- $\gamma$ production [145]. Avian $\mathrm{H} 5 \mathrm{~N} 1$ and H9N2 viruses can induce higher CCL5 production in $\mathrm{V}$ Y9V82 $\mathrm{T}$ cells, which may mediate the migration of $\mathrm{V}$ Y9V82 $\mathrm{T}$ cells toward influenza virus-infected cells [145].

In addition, Pam activated human Vy9V $\delta 2 \mathrm{~T}$ cells could kill influenza virus-infected cells and suppress viral replication in vitro. Tu et al. [146] demonstrated that Pam-expanded VY9Vס2 T cells by themselves can control influenza virus infection effectively in vivo. Regarding H1N1 viruses, the inhibition of the virus replication by the $\mathrm{V} \gamma 9 \mathrm{~V} \delta 2 \mathrm{~T}$ cells may rely on direct killing of virus-infected cells and secretion of IFN- $\gamma$, but, for H5N1 infection, mainly by direct killing.

The antiviral mechanisms elicited by $\mathrm{V} \gamma 9 \mathrm{~V} \delta 2 \mathrm{~T}$ cells during different viral infections are diverse. For example, human Vү9V82 T cells can kill Epstein-Barr virus (EBV)-, and herpes simplex virus 
(HSV)-infected target cells in an HLA-unrestricted manner in vitro [147]. IPP-activated Vy9V82 T cells can kill human immunodeficiency virus (HIV)-infected target cells and inhibit viral replication by releasing certain CCR5 ligand chemokines to block the HIV entry co-receptor CCR5. Furthermore, phosphoantigen-activated Vy9V82 $\mathrm{T}$ cells can induce noncytolytic inhibition of hepatitis $\mathrm{C}$ virus (HCV) replication by IFN- $\gamma$ secretion [148]. It was revealed that simian $\gamma \delta \mathrm{T}$ cells could produce $\beta$-chemokines, such as macrophage inflammatory protein-1a [MIP1- $\alpha]$, MIP1- $\beta$, and RANTES. These factors are known to block virus attachment to the CCR5 co-receptor [149], thus preventing SIV infection.

Furthermore, $\gamma \delta \mathrm{T}$ cells can induce the maturation of dendritic cells (DCs) to promote the establishment of protective adaptive immunity against West Nile virus [150]. The protective roles of $\gamma \delta$ T cells have also been confirmed in some chronic infectious diseases. During human cytomegalovirus (HCMV) infection [151], V82- $\mathrm{T}$ cells, a minor population of peripheral blood $\gamma \delta \mathrm{T}$ cells, have been found to expand significantly, showing a potent 'virus-specific' cytotoxicity and increased elimination of pathogens [152]. Similarly, $\gamma \delta \mathrm{T}$ cells in HIV-infected patients have been found to exhibit beneficial roles in controlling HIV infection [153] through their cell-lytic functions and cytokine secretions. $\gamma \delta \mathrm{T}$ cells are potent effectors in antibody-directed cell cytotoxicity [154], which is important for HIV inhibition [155], although the quantity and quality of $\gamma \delta \mathrm{T}$ cells are generally decreased with the advancement of HIV infection [156]. $\gamma \delta \mathrm{T}$ cells also help control the infection caused by Epstein-Barr virus [157] and human hepatitis virus C [158].

More recently, Yin's group found negative correlation between the ratios of V $22 \mathrm{~T}$ cells to Th17 (IL-17-producing $\mathrm{CD}^{+} \mathrm{T}$ ) cells and liver damage in $\mathrm{HBV}$-infected immune-activated patients and provided experimental evidence that V $\delta 2 \mathrm{~T}$ cells suppressed Th17 cytokine production through cell contact-dependent and IFN- $\gamma$-dependent mechanisms [116].

The applications of $\gamma \delta \mathrm{T}$ cells in the antiviral immunity are summarized in Table 2 .

\section{Bacterial infections}

The discovery that $\gamma \delta \mathrm{T}$ cells expanded in the peripheral blood of patients with bacterial infections raised the possibility that the $\mathrm{T}$ cell subset can be utilized for the control of bacterial infections. Mounting evidence indicates that $\gamma \delta \mathrm{T}$ cells are of importance in human bacterial infections. Human $\gamma \delta \mathrm{T}$ cells can recognize HMBPP derived from various bacteria and provoke adaptive immunity in various ways. They expand during bacterial infections such as tuberculosis (mean, 14\%), salmonellosis (mean, 18\%), tularemia (mean, 31\%), brucellosis (mean, 29\%), listeriosis (mean, 12\%), and ehrlichiosis (mean, 57\%). Activated and expanded $\mathrm{V} \gamma 2 \mathrm{~V} \delta 2^{+} \mathrm{T}$ cells might directly participate in antimicrobial immune responses. They recognize HMBPP in a TCR-dependent, MHC-, and CD1-unrestricted manner [6], then kill bacteria-infected cells and bacteria.

Tabel 2. Applications of $ү \delta T$-cell in the antiviral immunity.

\begin{tabular}{|c|c|c|}
\hline Virus Type & The Functions of $\gamma \delta$ T Cells & Ref. \\
\hline Influenza virus & $\begin{array}{l}\text { Cytotoxic and noncytolytic } \\
\text { antiviral activities }\end{array}$ & [144] \\
\hline $\begin{array}{l}\text { Simian immunodeficiency } \\
\text { virus (SIV) }\end{array}$ & $\begin{array}{l}\text { Produce } \beta \text {-chemokines, block } \\
\text { virus } \\
\text { attachment to the CCR } 5 \\
\text { co-receptor }\end{array}$ & [149] \\
\hline West Nile virus & $\begin{array}{l}\text { Induce the maturation of den- } \\
\text { dritic cells (DCs) }\end{array}$ & [150] \\
\hline $\begin{array}{l}\text { Human Cytomegalovirus } \\
(\mathrm{HCMV})\end{array}$ & $\begin{array}{l}\text { Have 'virus-specific' cytotoxi- } \\
\text { city }\end{array}$ & [151] \\
\hline $\begin{array}{l}\text { Human immunodeficiency } \\
\text { virus (HIV) }\end{array}$ & Cell-lysis and cytokine secretion & [153] \\
\hline Hepatitis C virus (HCV) & $\begin{array}{l}\text { Mediate non-(MHC)-restricted } \\
\text { killing of primary } \\
\text { hepatocytes, produce Th1-like } \\
\text { cytokine }\end{array}$ & [158] \\
\hline
\end{tabular}

Pontiac fever-like disease, which is caused by Legionella micdadei, was found to be related to a significant and long-lasting expansion of $\mathrm{V} \gamma 9 \mathrm{~V} \delta 2 \mathrm{~T}$ cells, implying that the subset may also be pathophysiologically important in a mild and transient form of intracellular bacterial diseases. Surprisingly, patients with the Pontiac fever-like disease showed an early depletion of Vy9V82 T cells from the circulation, followed by a sharp increase and subsequently, a slow decline over the next 6 months [159]. The ability of the $\gamma \delta \mathrm{T}$ cells to secrete IFN- $\gamma$ and TNF-a seemed to be down-regulated after the acute phase of the disease. These results support the assumption that Vy $9 \mathrm{~V} \delta 2 \mathrm{~T}$ cells are pathophysiologically important in intracellular bacterial infections, including a mild and transient condition such as Pontiac fever.

Moreover, some intracellular bacterial pathogens, such as Mycobacterium tuberculosis, can specifically expand and activate $\mathrm{V} \gamma 9 \mathrm{~V} \delta 2 \gamma \delta \mathrm{T}$ cells by inducing the production of metabolites (e.g., IPP) in infected cells, which strongly demonstrates that $\gamma \delta \mathrm{T}$ cells are crucially important in infection control [33]. Consistent with this finding, the suppression of $\gamma \delta \mathrm{T}$ cells by chronic tuberculosis infection can contribute to a disastrous outcome. 


\section{Other pathogen infections}

$\gamma \delta \mathrm{T}$ cells not only play protective roles in viral and bacterial infections, but also control infections by protozoas such as Leishmania [160] and Toxoplasma gondii [161], whereas the $\gamma \delta \mathrm{T}$ cell-mediated inflammation may cause some unwanted destruction of surrounding tissues. Similarly, the protective roles of $\gamma \delta \mathrm{T}$ cells during malaria infection have been confirmed in several independent studies [162].

\section{Applications of $y \delta T$-cell in autoimmune diseases}

In recent years, $\gamma \delta \mathrm{T}$ cells have been shown roles in the pathogenesis of autoimmune diseases such as rheumatoid arthritis (RA) and systemic lupus erythematosus (SLE). $\gamma \delta \mathrm{T}$ cells, by bridging innate and adaptive immunity, may display different functions similar to those of $\mathrm{CD}^{+}{ }^{+} \mathrm{T}$-cell subsets such as CTLs, Th1/Th2 cells, Tregs, Th17 cells, and APCs depending on specific microenvironment [163].

Rheumatoid arthritis (RA) is an autoimmune disease that primarily affects the limbs, but the pathogenic mechanism is still unclear. Research has demonstrated that $\gamma \delta \mathrm{T}$ cells can function as antigen-presenting cells and are related with rheumatoid arthritis development. During the development of rheumatoid arthritis, $\gamma \delta$ T cells can aggravate immune dysfunction and produce abnormal immune damage by the secretion of cytokines (such as IFN- $\gamma$ and IL-17) and induction of inflammatory cells to participate in synergistic inflammatory responses [164].

Systemic lupus erythematosus (SLE) is a common autoimmune disease with severe dysregulation of the immune system. Research suggested that the $\mathrm{CD}^{2} 7^{+} \mathrm{CD} 45 \mathrm{RA}^{-} \gamma \delta \mathrm{T}$ cells (a subset constitution of the peripheral blood $\gamma \delta \mathrm{T}$ cells) were significantly decreased in SLE patients and the numbers of $\mathrm{CD}^{2} 7^{+} \mathrm{CD}^{-} 5 \mathrm{RA}^{-} \gamma \delta \mathrm{T}$ cells was negatively correlated with the SLE disease activity. In inactive SLE patients following glucocorticosteroid and cyclophosphamide treatment, V $\delta 1$ cells were significantly increased. This research group also suggested that $\mathrm{CD} 27^{+} \mathrm{CD} 25^{\text {high }}$ V81 T cells had immunoregulatory activities through cell-to-cell contact, which could express Foxp3 similar to $\mathrm{CD}^{+}{ }^{+} \mathrm{Foxp}^{+}{ }^{+}$. These regulatory $\gamma \delta \mathrm{T}$ cells decreased in the peripheral blood of active SLE patients could be generated in vitro under the stimulation with anti-TCR $\gamma \delta$ in the presence of TGF- $\beta$ and IL-2 [165]. This finding provides a theoretical basis and feasibility for employing $\gamma \delta$ Tregs as a potential therapeutic target in autoimmune disease immunotherapy.

In addition, in an experimental autoimmune encephalomyelitis (EAE) model of the human CNS autoimmune disease multiple sclerosis, $\gamma \delta \mathrm{T}$ cells had been shown to regulate CNS inflammation and pro- mote disease recovery through Fas/FasL-induced apoptosis of encephalitogenic T cells [166].

\section{Applications of $y \delta T$-cell in allergic diseases}

Some researches have suggested that $\gamma \delta \mathrm{T}$ cells may serve as effectors and immunoregulatory cells in allergic disease. Atopic dermatitis (AD), a chronic relapsing inflammatory disease of the skin, is associated with allergic bronchial asthma. Cairo et al. [167] have observed that the circulating $\mathrm{V} \gamma 9 \mathrm{~V} \delta 2 \mathrm{~T}$ cells were significantly increased in AD patients, which is positively correlated between their expansion and the severity of the disease.

Zhang et al. demonstrated that $\gamma \delta$ T cells play a proinflammatory role in the development of ovalbumin-induced allergic airway inflammation [168]. Svensson et al. indicated that $\gamma \delta \mathrm{T}$ cells promote allergic airway inflammation by enhancing the systemic IgE response and local antibody reactivity without a specific role in the shift of the immune response towards Th2 [169]. IL- $17^{+} \gamma \delta \mathrm{T}$ cells, belonging to the $\mathrm{V} Y_{Y} 4$ subset, have been recently shown to downmodulate central features of allergic reaction in airway inflammation, including Th2 response and lung eosinophilia [143]. When activated, $\gamma \delta \mathrm{T}$ cells are able to produce a number of cytokines and chemokines, with a unique plasticity to produce Th1, Th2, and Th17 cytokines, contributing to the development and regulation of immune responses [170].

Furthermore, Pawankar et al. have observed an important role for the oligoclonally expanded nasal mucosal gamma delta $\mathrm{T}$ cells in the pathogenesis of perennial allergic rhinitis (PAR), with the increase of $\delta 1 \mathrm{~T}$ cells and able to produce mainly interleukin such as IL-4, IL-5 and IL-13 [171, 172].

\section{Summary}

In the previous paragraphs, we have elaborated on the mechanism of ligand recognition, activation, cytokine secretion, and applications of $\gamma \delta \mathrm{T}$ cells. To be understood better, we summarized the above-mentioned contents in Fig 3.

\section{Obstacles}

Clinical applications mentioned above provide enormous opportunities for accelerating the establishment of novel approaches to disease treatment and control, slowing disease progression, reducing comorbidities, and reducing or modifying requirements for antiretroviral therapy. People, however, envisage that some specific obstacles have to be overcome for the development of $\gamma \delta \mathrm{T}$ cell immunotherapies.

Firstly, clinical trials have demonstrated that repeated administration of phosphoantigens might 
cause anergy, exhaustion or even death of effector $\gamma \delta$ $\mathrm{T}$ cells. For instance, a macaque study showed that declining responses occurred after repeated BrHPP/IL-2 injections compared to the first treatment [173]. A similar pattern of declining responses was reported for Zol and IL-2 treatment in prostate cancer patients [66]. Thus, therapies targeting $\gamma \delta \mathrm{T}$ cells produce short-term responses for a long-term, chronic disease. If we can extend the duration of elevated $\gamma \delta \mathrm{T}$ cell levels and functions following treatment, repetitive dosing may not be necessary or the detrimental anergizing effect may not occur. Pauza and his colleagues [22] defined the protocol for $\gamma \delta \mathrm{T}$ cell activation, including adding immunomodulators such as rapamycin that increase the yield of the cells and potentially modulate the onset of anergy [18].

Secondly, immunostimulatory treatments may elicit significant adverse events (SAEs). For instance, activated $\gamma \delta \mathrm{T}$ cells will produce proinflammatory cytokines that may cause SAEs. People, therefore, must minimize or manage the potential consequences of immune reconstitution. These potential obstacles, the risk for SAEs and anergy, have to be addressed by definitively controlled human clinical trials.

Thirdly, although the activation of $\mathrm{V} \gamma 2 \mathrm{~V} \delta 2 \mathrm{~T}$ cells can contribute to the rapid acquisition of APC characteristics ( $\gamma \delta \mathrm{T}$-APCs), dominant $\mathrm{V} \gamma 2 \mathrm{~V} \delta 2 \mathrm{~T}$-cell subset capable of recognizing microbial phosphoantigen exist only in primates. Therefore, current task is to find an analogue to evaluate the characteristics and clinical potential (including side effects) in murine systems, which may be overcome by the development of a humanized mouse model. This is another current key barrier for the application of $\gamma \delta \mathrm{T}$ cells based immunotherapy.

\section{Outlooks}

Although great progress has been made in $\gamma \delta \mathrm{T}$ cell-based immunothearpies, many aspects need to be improved in future clinical trials.

Regarding tumor cells, it is necessary to explore the adjuvant effect of Toll-like receptor (TLR) stimulation, because in vitro treatment of tumor cells with TLR3 and TLR7 agonists could enhance cytotoxicity of $\gamma \delta \mathrm{T}$ cells isolated from cancer patients [174]. As for $\gamma \delta$ $\mathrm{T}$ cells, it will be of great importance to evaluate the clinical effects of synthetic TCR agonists such as phosphostim (BrHPP) and picostim (an analog of HMBPP). Another interesting feature is the use of phosphoantigens combined with therapeutic antibodies, as suggested by the improved leukemia and/or lymphoma in vitro killing after co-administration of BrHPP and rituximab [175]. In addition, it is important to evaluate the safety of TCR-independent killing strategy by comparing the NKG2D-mediated cytotoxicity against transformed and healthy tissues by NKG2D+ $\gamma \delta$ T cells.

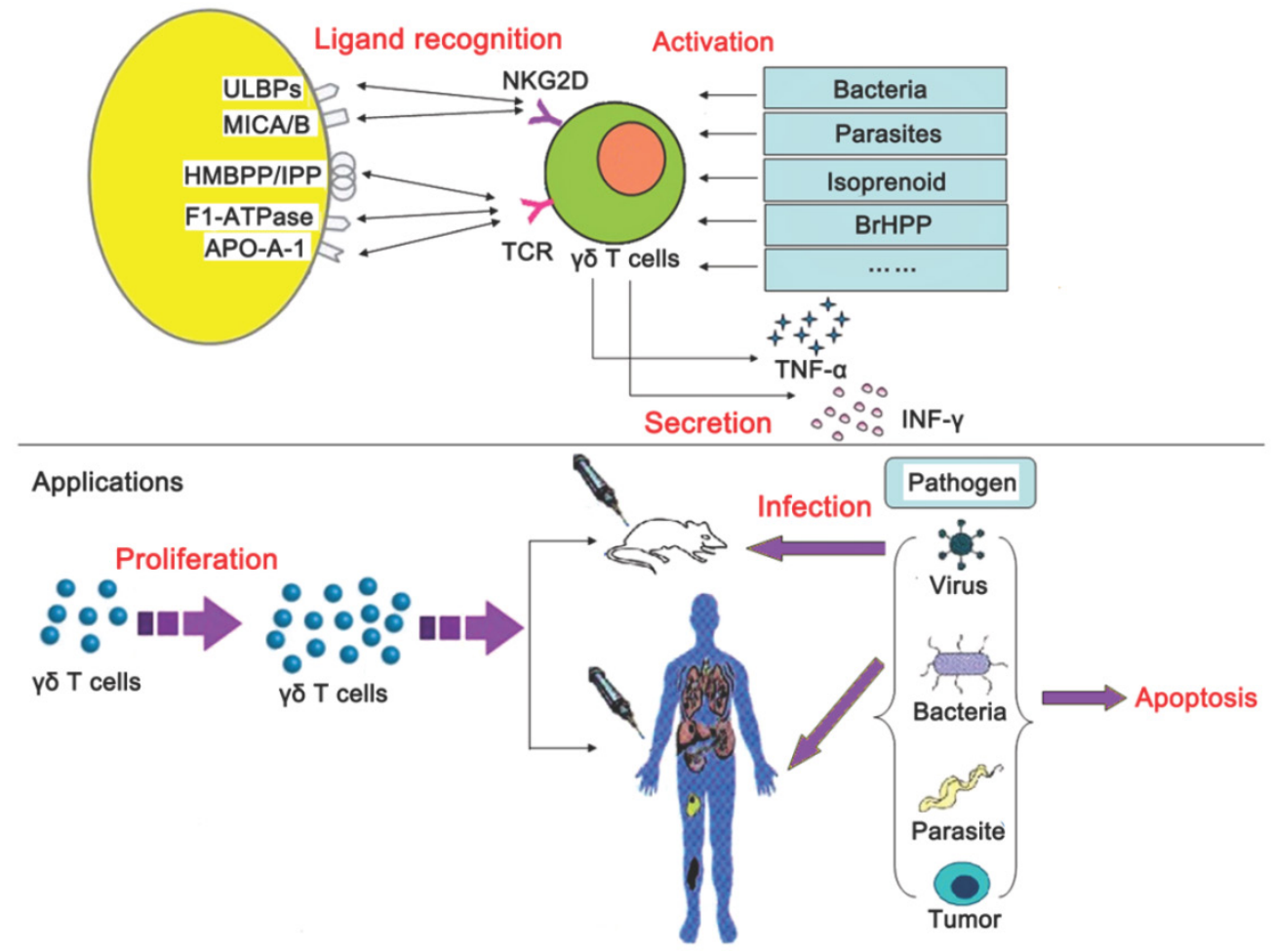

Figure 3. Mechanism underlying $ү \delta \mathrm{T}$ cell recognition of nonpeptide antigens and clinical applications. 
Finally, the identification of biomarkers to predict clinical outcome is crucial for patient selection. A recent study, for example, has identified a panel of 10 genes which encode cell surface proteins that segre-

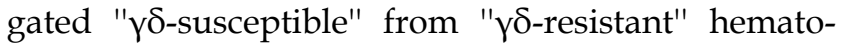
logic tumors [121]. Equivalent markers could be promptly characterized in multiple cancer types, and their predictive value should be accessed in $\gamma \delta \mathrm{T}$ cell-based clinical trials. The combination of "susceptible" tumor profiles with improved strategies for $\gamma \delta \mathrm{T}$ -cell activation in vivo may be the way forward for $\gamma \delta$ T cell-based cancer immunotherapy.

$\gamma \delta \mathrm{T}$ cells are attractive targets for cellular immunotherapy, but protocols for their therapeutic use need to be optimized. In addition, it is necessary to explore better antigens which help us stimulate $\gamma \delta \mathrm{T}$ cell expansion in vitro for the preparation of a large number of cells for adoptive cell transfer. Future studies should focus on the possible advantages of combining $\gamma \delta \mathrm{T}$ cell-based immunotherapy with conventional chemotherapy or other therapeutic approaches, such as antiangiogenic drugs.

\section{Acknowledgments}

We gratefully acknowledge the support by the Program for Zhejiang Leading Team of Science and Technology Innovation (2011R50021), Social Development project of Zhejiang Province (2011C23004) and Zhejiang provincial Natural Science Foundation of China (LY12B02019).

\section{Competing Interests}

The authors have declared that no competing interest exists.

\section{References}

1. Porritt HE, Rumfelt LL, Tabrizifard S, et al. Heterogeneity among DN1 prothymocytes reveals multiple progenitors with different capacities to generate $\mathrm{T}$ cell and non-T cell lineages. Immunity. 2004; 20: 735-745.

2. Allman D, Sambandam A, Kim S, et al. Thymopoiesis independent of common lymphoid progenitors. Nat Immunol. 2003; 4: 168-174.

3. Taghon T, Yui MA, Pant R, et al. Developmental and molecular characterization of emerging beta- and gammadelta-selected pre-T cells in the adult mouse thymus. Immunity. 2006; 24: 53-64.

4. Jabeen R, Chang HC, Goswami R, et al. The transcription factor PU.1 regulates $\gamma \delta \mathrm{T}$ cell homeostasis. PLoS One. 2011; 6: e22189.

5. Morita CT, Lee HK, Leslie DS, et al. Recognition of nonpeptide prenyl pyrophosphate antigens by human gammadelta T cells. Microbes Infect. 1999; 1: 175-186.

6. Tanaka Y, Morita CT, Tanaka Y, et al. Natural and synthetic non-peptide antigens recognized by human gamma delta T cells. Nature. 1995; 375: 155-158.

7. Bauer S, Groh V, Wu J, et al. Activation of NK cells and T cells by NKG2D, a receptor for stress-inducible MICA. Science. 1999; 285: 727-729.

8. Bukowski JF, Morita CT, Brenner MB. Human gamma delta T cells recognize alkylamines derived from microbes, edible plants, and tea: implications for innate immunity. Immunity. 1999; 11: 57-65.

9. Hayday AC. $\gamma \delta$ T cells: a right time and a right place for a conserved third way of protection. Annu Rev Immunol. 2000; 18: 975-1026.

10. Petermann F, Rothhammer V, Claussen MC, et al. $\gamma \delta \mathrm{T}$ cells enhance autoimmunity by restraining regulatory $\mathrm{T}$ cell responses via an interleukin-23-dependent mechanism. Immunity. 2010; 33: 351-363.

11. Kabelitz D, Glatzel A, Wesch D. Antigen recognition by human $\gamma \delta \mathrm{T}$ lymphocytes. International Archives of Allergy and Immunology. 2000; 122: 1-7.
12. Groh V, Steinle A, Bauer S, et al. Recognition of stress-induced MHC molecules by intestinal epithelial gammadelta T cells. Science. 1998; 279: 1737-1740.

13. Kapp JA, Kapp LM, McKenna KC, et al. gammadelta T-cell clones from intestinal intraepithelial lymphocytes inhibit development of CTL responses ex vivo. Immunology. 2004; 111: 155-164.

14. Gould DS, Ploegh HL, Schust DJ. Murine female reproductive tract intraepithelial lymphocytes display selection characteristics distinct from both peripheral and other mucosal T cells. J Reprod Immunol. 2001; 52: 85-99.

15. Poles MA, Barsoum $S, Y u$ W, et al. Human immunodeficiency virus type 1 induces persistent changes in mucosal and blood gammadelta $\mathrm{T}$ cells despite suppressive therapy. J Virol. 2003; 77: 10456-10467.

16. Rakasz E, MacDougall AV, Zayas MT, et al. Gammadelta T cell receptor repertoire in blood and colonic mucosa of rhesus macaques. J Med Primatol. 2000; 29: 387-396.

17. Moser B, Eberl M. $\gamma \delta$ T-APCs: a novel tool for immunotherapy? Cell Mol Life Sci. 2011; 68(14): 2443-2452.

18. $\mathrm{Li} \mathrm{H}$, Pauza CD. Rapamycin increases the yield and effector function of human $\gamma \delta$ T cells stimulated in vitro. Cancer Immunol Immunother. 2011; 60: 361-370.

19. Mangan BA, Dunne MR, O'Reilly VP, et al. Cutting edge: CD1d restriction and Th1/Th2/Th17 cytokine secretion by human V83 T cells. J Immunol. 2013; 191: 30-34.

20. Kabelitz D, Wesch D, He W. Perspectives of gamma delta T cells in tumor immunology. Cancer Res. 2007; 67: 5-8.

21. Cairo C, Armstrong CL, Cummings JS, et al. Impact of age, gender, and race on circulating $\gamma \delta$ T cells. Hum Immunol. 2010; 71: 968-975.

22. Pauza CD, Riedel DJ, Gilliam BL, et al. Targeting $\gamma \delta \mathrm{T}$ cells for immunotherapy of HIV disease. Future Virol. 2011; 6: 73-84.

23. Hayday AC. Gammadelta $\mathrm{T}$ cells and the lymphoid stress-surveillance response. Immunity. 2009; 31: 184-196.

24. Caccamo N, Dieli F, Wesch D, et al. Sex-specific phenotypical and functional differences in peripheral human Vgamma9/Vdelta2 T cells. J Leukoc Biol. 2006; 79: 663-666.

25. Allison TJ, Winter CC, Fournié JJ, et al. Structure of a human gammadelta T-cell antigen receptor. Nature. 2001; 411: 820-824.

26. Morita CT, Beckman EM, Bukowski JF, et al. Direct presentation of nonpeptide prenyl pyrophosphate antigens to human gamma delta $\mathrm{T}$ cells. Immunity. 1995; 3: 495-507.

27. Scotet E, Martinez LO, Grant E, et al. Tumor recognition following Vgamma9Vdelta2 $\mathrm{T}$ cell receptor interactions with a surface F1-ATPase-related structure and apolipoprotein A-1. Immunity. 2005; 22: 71-80.

28. Harly C, Guillaume $Y$, Nedellec $S$, et al. Key implication of CD277/butyrophilin-3 (BTN3A) in cellular stress sensing by a major human үठ T-cell subset. Blood. 2012; 120: 2269-2279.

29. Jr Janeway CA, Jones B, Hayday A. Specificity and function of T cells bearing $\gamma \delta$ receptors. Immunol Today. 1988; 9: 73-76.

30. Bluestone JA, Khattri R, Sciammas R, et al. TCR gamma delta cells: a specialized T cell subset in the immune system. Annu Rev Cell Dev Biol. 1995; 11: 307-353.

31. Kazen AR, Adams EJ. Evolution of the V, D, and J gene segments used in the primate gammadelta T-cell receptor reveals a dichotomy of conservation and diversity. Proc Natl Acad Sci USA. 2011; 108: E332-340.

32. Beagley KW, Husband AJ. Intraepithelial lymphocytes: origins, distribution, and function. Crit Rev Immunol. 1998; 18(3): 237-254.

33. Zheng J, Liu Y, Lau YL, et al. $\gamma \delta$-T cells: an unpolished sword in human anti-infection immunity. Cell Mol Immunol. 2013; 10(1): 50-57.

34. Pfeffer K, Schoel B, Gulle H, et al. Primary responses of human T cells to mycobacteria: a frequent set of gamma/delta $\mathrm{T}$ cells are stimulated by protease-resistant ligands. Eur J Immunol. 1990; 20: 1175-1179.

35. Pfeffer $\mathrm{K}$, Schoel B, Plesnila N, et al. A lectin-binding, protease-resistant mycobacterial ligand specifically activates Vgamma9 ${ }^{+}$human gamma delta $\mathrm{T}$ cells. J lmmunol. 1992; 148: 575-583.

36. Porcelli SA, Morita CT, Modlin RL. T-cell recognition of non-peptide antigens. Curr Opin Immunol. 1996; 8: 510-516.

37. Burk MR, Mori L, De Libero G. Human V gamma 9-Vdelta 2 cells are stimulated in a cross-reactive fashion by a variety of phosphorylated metabolites. Eur J fmmunol, 1995; 25: 2052-2058.

38. Tanaka Y, Morita CT, Nieves E, et al. Natural and synthetic nonpeptide antigens recognized by human gamma/delta T cells. Nature. 1995; 375: 55-58.

39. Wang H, Fang Z, Morita CT. Vgamma2Vdelta2 T Cell Receptor recognition of prenyl pyrophosphates is dependent on all CDRs. J Immunol. 2010; 184(11): 6209-6222.

40. Vavassori S, Kumar A, Wan GS, et al. Butyrophilin 3A1 binds phosphorylated antigens and stimulates human $\gamma \delta$ T cells. Nat Immunol. 2013; 14: 908-916.

41. Messal N, Mamessier E, Sylvain A, et al. Differential role for CD277 as a co-regulator of the immune signal in T and NK cells. Eur J Immunol. 2011; 41: 3443-3454.

42. Wang H, Henry O, Distefano MD, et al. Butyrophilin $3 \mathrm{~A} 1$ plays an essential role in prenyl pyrophosphate stimulation of human $\mathrm{V} \gamma 2 \mathrm{~V} \delta 2 \mathrm{~T}$ cells. J Immunol. 2013; 191: 1029-1042

43. Agea E, Russano A, Bistoni O, et al. Human CD1-restricted T cell recognition of lipids from pollens. J Exp Med. 2005; 202(2): 295-308.

44. Dieudé M, Striegl H, Tyznik AJ, et al. Cardiolipin binds to CD1d and stimulates CD1d-restricted $\gamma \delta \mathrm{T}$ cells in the normal murine repertoire. J Immunol. 2011; 186(8): 4771-4781. 
45. Born WK, Kemal Aydintug M, O'Brien RL. Diversity of $\gamma \delta$ T-cell antigens. Cell Mol Immunol. 2013; 10(1): 13-20.

46. Willcox CR, Pitard V, Netzer S, et al. Cytomegalovirus and tumor stress surveillance by binding of a human $\gamma \delta \mathrm{T}$ cell antigen receptor to endothelial protein C receptor. Nat Immunol. 2012; 13: 872-879.

47. Rust CJ, Verreck F, Vietor H, et al. Specific recognition of staphylococcal enterotoxin $\mathrm{A}$ by human $\mathrm{T}$ cells bearing receptors with the $\mathrm{V}$ gamma 9 region. Nature. 1990; 346(6284): 572-574.

48. Guo Y, Ziegler HK, Safley SA, et al. Human T-cell recognition of Listeria monocytogenes: recognition of listeriolysin $\mathrm{O}$ by TcR alpha beta ${ }^{+}$and $\mathrm{TcR}$ gamma delta ${ }^{+}$T cells. Infect Immun. 1995; 63(6): 2288-2294.

49. Champagne E. $\gamma \delta \mathrm{T}$ cell receptor ligands and modes of antigen recognition. Arch Immunol Ther Exp (Warsz). 2011; 59(2):117-137.

50. Zhao Y, Yokota K, Ayada K, et al. Helicobacter pylori heat-shock protein 60 induces interleukin-8 via a Toll-like receptor (TLR)2 and mitogen-activated protein (MAP) kinase pathway in human monocytes. J Med Microbiol. 2007; 56(Pt 2): 154-164.

51. Tsan MF, Gao B. Heat shock proteins and immune system. J Leukoc Biol. 2009; 85(6): 905-910.

52. Bai L, Picard D, Anderson B, et al. The majority of CD1d-sulfatide-specific T cells in human blood use a semiinvariant V81 TCR. Eur J Immunol. 2012; 42(9):2505-2510.

53. Lanca T, Correia DV, Moita CF, et al. The MHC class Ib protein ULBP1 is a nonredundant determinant of leukemia/lymphoma susceptibility to gammadelta T-cell cytotoxicity. Blood. 2010; 115: 2407-2411.

54. Kong Y, Cao W, Xi X, et al. The NKG2D ligand ULBP4 binds to TCR gamma9/delta2 and induces cytotoxicity to tumor cells through both TCR gammadelta and NKG2D. Blood. 2009; 114: 310-317.

55. Chien YH, Jores R, Crowley MP. Recognition by gamma/delta T cells. Annu Rev Immunol. 1996; 14: 511-532.

56. Asarnow DM, Kuziel WA, Bonyhadi M, Tigelaar RE, Tucker PW, Allison JP. Limited diversity of gamma delta antigen receptor genes of Thy-1+ dendritic epidermal cells. Cell. 1988; 55: 837-847.

57. Adams EJ, Chien $\mathrm{YH}$, Garcia KC. Structure of a gammadelta T cell receptor in complex with the nonclassical MHC T22. Science. 2005; 308: 227-231.

58. Pechhold K, Wesch D, Schondelmaier S, et al. Primary activation of V gamma 9-expressing gamma delta $\mathrm{T}$ cells by Mycobacterium tuberculosis. Requirement for Th1-type CD4 T cell help and inhibition by IL-10. J Immunol. 1994; 152(10): 4984-4992.

59. Behr C, Poupot R, Peyrat MA, et al. Plasmodium falciparum stimuli for human gammadelta $\mathrm{T}$ cells are related to phosphorylated antigens of mycobacteria. Infect Immun. 1996; 64(8): 2892-2896.

60. Arigoni D, Sagner S, Latzel C, et al. Terpenoid biosynthesis from 1-deoxy-D-xylulose in higher plants by intramolecular skeletal rearrangement. Proc Natl Acad Sci USA. 1997; 94: 10600-10605.

61. Espinosa E, Belmant C, Pont F, et al. Chemical synthesis and biological activity of bromohydrin pyrophosphate, a potent stimulator of human gamma delta $\mathrm{T}$ cells. J Biol Chem. 2001; 276: 18337-18344.

62. Rincon-Orozco B, Kunzmann V, Wrobel P, et al. Activation of Vgamma9Vdelta2 T cells by NKG2D. J Immunol. 2005; 175: 2144-2151.

63. Hebbeler AM, Cairo C, Cummings JS, et al. Individual Vgamma2-Jgamma1.2+ $\mathrm{T}$ cells respond to both isopentenyl pyrophosphate and Daudi cell stimulation: generating tumor effectors with low molecular weight phosphoantigens. Cancer Immunol Immunother. 2007; 56: 819-829.

64. Zgani I, Menut C, Seman M, et al. Synthesis of prenyl pyrophosphonates as new potent phosphoantigens inducing selective activation of human Vgamma9Vdelta2 T lymphocytes. J Med Chem. 2004; 47: 4600-4612.

65. Bonneville M, Scotet E. Human Vgamma9Vdelta2 T cells: promising new leads for immunotherapy of infections and tumors. Curr Opin Immunol. 2006; 18: 539-546

66. Gober HJ, Kistowska M, Angman L, et al. De Libero G. Human T cell receptor gammadelta $\mathrm{T}$ cells recognize endogenous mevalonate metabolites in tumor cells. J Exp Med. 2003; 197: 163-168.

67. Dieli F, Vermijlen D, Fulfaro F, et al. Targeting human gammadelta T cells with zoledronate and interleukin-2 for immunotherapy of hormone-refractory prostate cancer. Cancer Res. 2007; 67: 7450-7457.

68. Kim S, Iizuka K, Aguila HL, et al. In vivo natural killer cell activities revealed by natural killer cell-deficient mice. Proc Natl Acad Sci USA. 2000; 97: 2731-2736.

69. Nishio N, Fujita M, Tanaka Y, et al. Zoledronate sensitizes neuroblastoma-derived tumor-initiating cells to cytolysis mediated by human $\gamma \delta$ T cells. J Immunother. 2012; 35: 598-606

70. Idrees ASM, Sugie T, Inoue C, et al. Comparison of $\gamma \delta \mathrm{T}$ cell responses and farnesyl diphosphate synthase inhibition in tumor cells pretreated with zoledronic acid. Cancer Sci. 2013; 104: 536-542.

71. Miyagawa F, Tanaka Y, Yamashita S, et al. Essential requirement of antigen presentation by monocyte lineage cells for the activation of primary human gamma delta T cells by aminobisphosphonate antigen. J Immunol. 2001; 166: 5508-5514.

72. Brandes M, Willimann K, Moser B. Professional antigen-presentation function by human gamma delta T cells. Science. 2005; 309: 264-268.

73. Shin S, El-Diwany R, Schaffert S, et al. Antigen recognition determinants of gamma delta T cell receptors. Science. 2005; 308: 252-255.

74. Sarikonda G, Wang H, Puan KJ, et al. Photoaffinity antigens for human gammadelta T cells. J Immunol. 2008; 181: 7738-7750.
75. Wei H, Huang D, Lai X, et al. Definition of APC presentation of phosphoantigen (E)-4-hydroxy-3-methyl-but-2-enyl pyrophosphate to Vgamma2Vdelta2 TCR. J Immunol. 2008; 181: 4798-4806.

76. Kabelitz D. CD277 takes the lead in human T-cell activation. Blood. 2012; 120: 2159-2161.

77. Sutton CE, Lalor SJ, Sweeney CM, et al. Interleukin-1 and IL-23 induce innate IL-17 production from gammadelta T cells, amplifying Th17 responses and autoimmunity. Immunity. 2009; 31: 331-341.

78. Eberl M, Engel R, Beck E, Jomaa H. Differentiation of human gamma-delta T cells towards distinct memory phenotypes. Cell Imminol. 2002; 218(1-2): 1-6.

79. Ribot JC, deBarros A, Pang DJ, et al. CD27 is a thymic determinant of the balance between interferon-gamma- and interleukin 17-producing gammadelta T cell subsets. Nat Immunol. 2009; 10: 427-436.

80. Gioia C, Agrati C, Casetti R, et al. Lack of CD27-CD45RA-Vgamma 9V delta2+ $\mathrm{T}$ cell effectors in immunocompromised hosts and during active pulmonary tuberculosis. J Immunol. 2002; 168: 1484-1489.

81. Cho JS, Pietras EM, Garcia NC, et al. IL-17 is essential for host defense against cutaneous Staphylococcus aureus infection in mice. J Clin Invest. 2010; 120: 1762-1773.

82. Ribot JC, Debarros A, Silva-Santos B. Searching for "signal 2": costimulation requirements of gammadelta T cells. Cell Mol Life Sci. 2011; 68: 2345-2355.

83. Sarikonda G, Wang H, Puan KJ, et al . Photoaffinity antigens for human cdT Cells. J Immunol. 2008; 181: 7738-7750.

84. Budd RC, Russell JQ, van Houten N, et al. CD2 expression correlates with proliferative capacity of alpha beta 1 or gamma delta1 CD42 CD82 T cells in lpr mice. J Immunol. 1992; 148: 1055-1064.

85. Lafont V, Liautard J, Gross A, et al. Tumor necrosis factor-alpha production is differently regulated in gamma delta and alpha beta human $\mathrm{T}$ lymphocytes. J Biol Chem. 2000; 275: 19282-19287.

86. Mohan JF, Levisetti MG, Calderon B, et al . Unique autoreactive T cells recognize insulin peptides generated within the islets of Langerhans in autoimmune diabetes. Nat Immunol. 2010; 11: 350-354.

87. Kozbor D, Trinchieri G, Monos DS, et al. Human TCR-gamma1/delta1, CD81 T lymphocytes recognize tetanus toxoid in an MHC-restricted fashion. J Exp Med. 1989; 169: 1847-1851.

88. Silva-Santos B, Pennington DJ, Hayday AC. Lymphotoxin-mediated regulation of gammadelta cell differentiation by alphabeta $\mathrm{T}$ cell progenitors. Science. 2005; 307: 925-928.

89. Vantourout $P$, Hayday A. Six-of-the-best: unique contributions of $\gamma \delta$ T cells to immunology. Nat Rev Immunol. 2013; 13(2):88-100.

90. Caccamo N, Battistini L, Bonneville M, et al. CXCR5 identifies a subset of Vgamma9Vdelta2 T cells which secrete IL-4 and IL-10 and help B cells for antibody production. Immunol. 2006; 177(8): 5290-5295.

91. Devilder MC, Maillet S, Bouyge-Moreau I, et al. Potentiation of antigen-stimulated Vgamma9Vdelta2 $\mathrm{T}$ cell cytokine production by immature dendritic cells (DC) and reciprocal effect on DC maturation. J Immunol. 2006; 176: 1386-1393.

92. Ismaili J, Olislagers $\mathrm{V}$, Poupot $\mathrm{M}$, et al. Human gamma delta T cells induce dendritic cell maturation. Clin Immunol. 2002; 103: 296-302

93. Leslie DS, Vincent MS, Spada FM, et al. CD1-mediated gamma/delta T cell maturation of dendritic cells. J Exp Med. 2002; 196: 1575-1584.

94. Collins C, Wolfe J, Roessner K, et al. Lyme arthritis synovial gammadelta T cells instruct dendritic cells via fas ligand. The Journal of Immunology. 2005; 175: 5656-5665.

95. Dieli F, Caccamo N, Meraviglia S, et al. Reciprocal stimulation of gammadelta $\mathrm{T}$ cells and dendritic cells during the anti-mycobacterial immune response. Eur J Immunol. 2004; 34: 3227-3235.

96. Martino A, Casetti R, D'Alessandri A, et al. Complementary function of gamma delta T-lymphocytes and dendritic cells in the response to isopentenyl-pyrophosphate and lipopolysaccharide antigens. J Clin Immunol. 2005; 25: 230-237.

97. DiTirro J, Rhoades ER, Roberts AD, et al. Disruption of the cellular inflammatory response to Listeria monocytogenes infection in mice with disruptions in targeted genes. Infect Immun. 1998; 66: 2284-2289.

98. Sharp LL, Jameson JM, Cauvi G, et al. Dendritic epidermal T cells regulate skin homeostasis through local production of insulin-like growth factor 1 . Nat Immunol. 2005; 6: 73-79.

99. Jameson JM, Cauvi G, Sharp LL, et al. Gammadelta T cell-induced hyaluronan production by epithelial cells regulates inflammation. J Exp Med. 2005; 201: 1269-1279.

100. Skeen MJ, Freeman MM, Ziegler HK. Changes in peritoneal myeloid populations and their proinflammatory cytokine expression during infection with Listeria monocytogenes are altered in the absence of gamma/delta T cells. J Leukocyte Biol. 2004; 76: 104-115.

101. Schilbach KE, Geiselhart A, Wessels J T, et al. Human gammadelta T lymphocytes exert natural and IL-2-induced cytotoxicity to neuroblastoma cells. J Immunother. 2000; 23: 536-548.

102. Todaro M, D'Asarob M, Caccamo N, et al. Efficient killing of human colon cancer atem cells by gammadelta T lymphocytes. J Immunol. 2009; 182: 7287-7296.

103. D'Asaro M., La Mendola C, Di Liberto D, et al. V gamma 9V delta 2 T lymphocytes efficiently recognize and kill zoledronate-sensitized, imatinib-sensitive, and imatinib-resistant chronic myelogenous leukemia cells. J Immunol. 2010; 184: 3260-3268. 
104. Chargui J, Combaret V, Scaglione V, et al. Bromohydrin pyrophosphate-stimulated Vgamma9delta2 T cells expanded ex vivo from patients with poor-prognosis neuroblastoma lyse autologous primary tumor cells. J Immunother. 2010; 33: 591-598.

105. Kato Y, Tanaka Y, Tanaka H, et al. Requirement of species-specific interactions for the activation of human gamma delta T cells by pamidronate. J Immunol. 2003; 170: 3608-3613.

106. Kato Y, Tanaka Y, Hayashi M, et al. Involvement of CD166 in the activation of human gamma delta $\mathrm{T}$ cells by tumor cells sensitized with nonpeptide antigens. J Immunol. 2006; 177: 877-884.

107. Li W, Kubo S, Okuda A, et al. Effect of IL-18 on expansion of gammadelta T cells stimulated by zoledronate and IL-2. J Immunother. 2010; 33: 287-296.

108. Laggner U, Di Meglio P, Perera GK, et al. Identification of a novel proinflammatory human skin-homing V $\gamma 9 \mathrm{~V} \delta 2 \mathrm{~T}$ cell subset with a potential role in psoriasis. J Immunol. 2011; 187(5): 2783-2793.

109. Brandes M, Willimann K, Moser B. Professional antigen-presentation function by human gammadelta T Cells. Science. 2005; 309(5732): 264-268.

110. Li H, Luo K, Pauza CD. TNF-alpha is a positive regulatory factor for human Vgamma2Vdelta2 T cells. J Immunol. 2008; 181: 7131-7137.

111. van den Broek MF, Muller U, et al. Immune defence in mice lacking type I and/or type II interferon receptors. Immunological Reviews. 1995; 148: 5-18.

112. Beetz S, Wesch D, Marischen L, et al. Innate immune functions of human gammadelta T cells. Immunobiology. 2008; 213: 173-182.

113. Spinozzi F, Agea E, Bistoni O, et al. Local expansion of allergen-specific CD30+Th2-type gamma delta T cells in bronchial asthma. Mol Med. 1995; 1: $821-826$.

114. Rhodes KA, Andrew EM, Newton DJ, et al. A subset of IL-10-producing gammadelta $\mathrm{T}$ cells protect the liver from Listeria-elicited, CD8 (+) T cell-mediated injury. Eur J Immunol. 2008; 8: 2274-2283.

115. Jensen KD, Su X, Shin S, et al. Thymic selection determines gammadelta $T$ cell effector fate: antigen-naive cells make interleukin-17 and antigen-experienced cells make interferon gamma. Immunity. 2008; 29: 90-100.

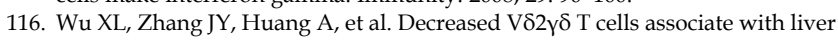
damage through regulating Th17 response in chronic hepatitis B patients. J Infect Dis. 2013; doi:10.1093/infdis/jit312.

117. Monforte A, Abrams D, Pradier C, et al. HIV-induced immunodeficiency and mortality from AIDS-defining and non-AIDS-defining malignancies. AIDS. 2008; 22: 2143-2153.

118. Salavoura K, Kolialexi A, Tsangaris G, et al. Development of cancer in patients with primary immunodeficiencies. Anticancer Research. 2008; 28: 1263-1269.

119. Waldmann TA. Immunotherapy: past, present and future. Nature Medicine. 2003; 9: 269-277.

120. Cordova A, Toia F, La Mendola C, et al. Characterization of human $\gamma \delta \mathrm{T}$ lymphocytes infiltrating primary malignant melanomas. PLoS One. 2012; 7(11): e49878.

121. Gomes AQ, Correia DV, Grosso AR, et al. Identification of a panel of ten cell surface protein antigens associated with immunotargeting of leukemias and lymphomas by peripheral blood gamma delta T cells. Haematologica. 2010; 95 : 1397-1404.

122. Liu Z, Guo BL, Gehrs BC, et al. Ex vivo expanded human Vgamma9Vdelta2 gammadelta-T cells mediate innate antitumor activity against human prostate cancer cells in vitro. J Urol. 2005; 173:1552-1556.

123. Saito A, Narita M, Yokoyama A, et al. Enhancement of anti-tumor cytotoxicity of expanded gammadelta $\mathrm{T}$ cells by stimulation with monocyte-derived dendritic cells. J Clin Exp Hematop. 2007; 47: 61-72.

124. Ferrarini M, Pupa SM, Zocchi MR, et al. Distinct pattern of HSP72 and monomeric laminin receptor expression in human lung cancers infiltrated by gamma/delta T lymphocytes. Int J Cancer. 1994; 57: 486-490.

125. Choudhary A, Davodeau F, Moreau A, et al. Selective lysis of autologous tumor cells by recurrent gamma delta tumor-infiltrating lymphocytes from renal carcinoma. J Immunol. 1995; 154: 3932-3940.

126. Dhar S, Chiplunkar SV. Lysis of aminobisphosphonate-sensitized MCF-7 breast tumor cells by Vү9V82 cells. Cancer Immun. 2010; 10: 10.

127. Lamb LS Jr, Henslee-Downey PJ, Parrish RS, et al. Increased frequency of TCR $\gamma \delta^{+} \mathrm{T}$ cells in disease-free survivors following T cell-depleted, partially mismatched, related donor bone marrow transplantation for leukemia. J Hematother. 1996; 5: 503-509.

128. Viey E, Fromont G, Escudier B, et al. Phosphostim-activated gamma delta T cells kill autologous metastatic renal cell carcinoma. J Immunol. 2005; 174: 1338-1347.

129. Sugie T, Murata-Hirai K, Iwasaki M, et al. Zoledronic acid-induced expansion of $\gamma \delta \mathrm{T}$ cells from early-stage breast cancer patients: effect of IL-18 on helper NK cells. Cancer Immunol Immunother. 2013; 62: 677-687.

130. Liotta LA, Kohn EC. The microenvironment of the tumour-host interface. Nature. 2001; 411: 375-379.

131. Brandes M, Willimann K, Bioley G, et al. Cross-presenting human gammadelta $\mathrm{T}$ cells induce robust $\mathrm{CD} 8^{+}$alpha beta $\mathrm{T}$ cell responses. Proc Natl Acad Sci USA. 2009; 106: 2307-2312.

132. Kabelitz D, Wesch D. Features and functions of gammadelta T lymphocytes: focus on chemokines and their receptors. Crit Rev Immunol. 2003; 23: 339-370.

133. Bennouna J, Bompas E, Neidhardt EM, et al. Phase-I study of Innacell gammadelta, an autologous cell-therapy product highly enriched in gamma9delta2 $\mathrm{T}$ lymphocytes, in combination with IL-2, in patients with metastatic renal cell carcinoma. Cancer Immunol Immunother. 2008; 57: 1599-1609.
134. Dokouhaki P, Han M, Joe B, et al. Adoptive immunotherapy of cancer using ex vivo expanded human $\gamma \delta$ T cells: A new approach. Cancer Lett. 2010; 297: 126-136.

135. Kikuchi E, Yamazaki K, Torigoe T, et al. HLA class I antigen expression is associated with a favorable prognosis in early stage non-small cell lung cancer. Cancer Sci. 2007; 98: 1424-1430.

136. Meraviglia S, Eberl M, Vermijlen D, et al. In vivo manipulation of Vy $9 \mathrm{~V} \delta 2 \mathrm{~T}$ cells with zoledronate and low-dose interleukin-2 for immunotherapy of advanced breast cancer patients. Clin Exp Immunol. 2010; 161: 290-297.

137. Kobayashi H, Tanaka Y, Shimmura H, et al. Complete remission of lung metastasis following adoptive immunotherapy using activated autologous gammadelta T-cells in a patient with renal cell carcinoma. Anticancer Res. 2010; 30: 575-579.

138. Wilhelm M, Kunzmann V, Eckstein S, et al. $\gamma \delta$ T cells for immune therapy of patients with lymphoid malignancies. Blood. 2003; 102: 200-206.

139. Corvaisier M, Moreau-Aubry A, Diez E, et al. V gamma $9 \mathrm{~V}$ delta $2 \mathrm{~T}$ cell response to colon carcinoma cells. J Immunol. 2005; 175: 5481-5488.

140. Marten A, Lilienfeld-Toal M, Buchler MW, et al. Zoledronic acid has direct antiproliferative and antimetastatic effect on pancreatic carcinoma cells and acts as an antigen for delta2 gamma/delta T cells. J Immunother. 2007; 30: 370-377.

141. Lalor SJ, Dungan LS, Sutton CE, et al. Caspase-1-processed cytokines IL-1b and IL-18 promote IL-17 production by $\gamma \delta$ and CD4 T cells that mediate autoimmunity. J Immunol. 2011; 186: 5738-5748.

142. Fink DR, Holm D, Schlosser A, et al. Elevated numbers of SCART11 gammadelta $\mathrm{T}$ cells in skin inflammation and inflammatory bowel disease. Mol Immunol. 2010; 47: 1710-1718.

143. Murdoch JR, Lloyd CM. Resolution of allergic airway inflammation and airway hyperreactivity is mediated by IL-17 producing $\gamma \delta$ T cells. Am J Respir Crit Care Med. 2010; 182: 464-476.

144. Oin G, Mao H, Zheng J, et al. Phosphoantigen-expanded human gammadelta $\mathrm{T}$ cells display potent cytotoxicity against monocyte-derived macrophages infected with human and avian influenza viruses. J Infect Dis. 2009; 200: 858-865.

145. Qin G, Liu Y, Zheng J, et al. Type 1 responses of human Vy9V82 T cells to influenza A viruses. J Virol. 2011; 85(19): 10109-10116.

146. Tu W, Zheng J, Liu Y, et al. The aminobisphosphonate pamidronate controls influenza pathogenesis by expanding a gammadelta $\mathrm{T}$ cell population in humanized mice. J Exp Med. 2011; 208(7): 1511-1522.

147. Fujishima N, Hirokawa M, Fujishima M, et al. Skewed T cell receptor repertoire of $\mathrm{V} \delta 1^{+} \mathrm{T}$ lymphocytes after human allogeneic haematopoietic stem cell transplantation and the potential role for Epstein-Barr virus-infected B cells in clonal restriction. Clin Exp Immunol. 2007; 149: 70-79.

148. Agrati C, Alonzi T, De Santis R, et al. Activation of Vү $9 \mathrm{~V} \delta 2 \mathrm{~T}$ cells by non-peptidic antigens induces the inhibition of subgenomic HCV replication. Int Immunol. 2006; 18: 11-18.

149. Tikhonov I, Deetz CO, Paca R, et al. Human Vgamma2Vdelta2 T cells contain cytoplasmic RANTES. Int Immunol. 2006; 18: 1243-1251.

150. Fang $H$, Welte $T$, Zheng $X$, et al. Gamma delta $T$ cells promote the maturation of dendritic cells during West Nile virus infection. FEMS Immunol Med Microbiol. 2010; 59: 71-80.

151. Knight A, Madrigal AJ, Grace S, et al. The role of Vdelta2-negative gamma-delta $\mathrm{T}$ cells during cytomegalovirus reactivation in recipients of allogeneic stem cell transplants. Blood. 2010; 116: 2164-2172.

152. Devaud C, Bilhere E, Loizon $S$, et al. Antitumor activity of $T$ cells reactive against cytomegalovirus-infected cells in a mouse xenograft tumor model. Cancer Res. 2009; 69: 3971-3978.

153. Sciammas R, Bluestone JA. TCR gamma delta cells and viruses. Microbes Infect. 1999; 1: 203-212.

154. Chen Z, Freedman MS. CD16 ${ }^{+}$gamma delta T cells mediate antibody dependent cellular cytotoxicity: potential mechanism in the pathogenesis of multiple sclerosis. Clin Immunol. 2008; 128: 219-227.

155. Riedel DJ, Sajadi MM, Armstrong CL, et al. Natural viral suppressors of HIV-1 have a unique capacity to maintain gammadelta T cells. AIDS. 2009; 23: 1955-1964.

156. Poccia F, Gioia C, Martini F, et al. Zoledronic acid and interleukin-2 treatment improves immunocompetence in HIV-infected persons by activating Vgamma9Vdelta2 T cells. AIDS. 2009; 23: 555-565.

157. de Paoli P, Gennari D, Martelli P, et al. Gammadelta T cell receptor-bearing lymphocytes during Epstein-Barr virus infection. J Infect Dis. 1990; 161: 1013-1016.

158. Tseng CT, Miskovsky E, Houghton M, et al. Characterization of liver T-cell receptor gammadelta $\mathrm{T}$ cells obtained from individuals chronically infected with hepatitis $\mathrm{C}$ virus (HCV): evidence for these $\mathrm{T}$ cells playing a role in the liver pathology associated with HCV infections. Hepatology. 2001; 33: 1312-1320.

159. Kroca M, Johansson A, Sjöstedt A, et al. V gamma $9 \mathrm{~V}$ delta $2 \mathrm{~T}$ cells in human legionellosis. Clin Diagn Lab Immunol. 2001; 8(5): 949-954.

160. Xu S, Han Y, Xu X, et al. IL-17A-producing $\gamma \delta \mathrm{T}$ cells promote CTL responses against Listeria monocyto genes infection by enhancing dendritic cell cross-presentation. J Immunol. 2010; 185: 5879-5887.

161. Egan CE, Dalton JE, Andrew EM, et al. A requirement for the Vgamma1+ subset of peripheral gammadelta T cells in the control of the systemic growth of Toxoplasma gondii and infection-induced pathology. J Immunol. 2005; 175: 8191-8199. 
162. Costa G, Loizon S, Guenot M, et al. Control of Plasmodium falciparum erythrocytic cycle: $\gamma \delta \mathrm{T}$ cells target the red blood cell-invasive merozoites. Blood. 2011; 118(26): 6952-6962.

163. Su D, Shen M, Li X, et al. Roles of $\gamma \delta \mathrm{T}$ cells in the pathogenesis of autoimmune diseases. Clin Dev Immunol. 2013; 2013: 985753.

164. Hu C, Qian L, Miao Y, et al. Antigen-presenting effects of effector memory VY9V82 T cells in rheumatoid arthritis. Cell Mol Immunol. 2012; 9(3): 245-254.

165. Li X, Kang N, Zhang X, et al. Generation of human regulatory gammadelta $\mathrm{T}$ cells by TCR gammadelta stimulation in the presence of TGF-beta and their involvement in the pathogenesis of systemic lupus erythematosus. J Immunol. 2011; 186(12): 6693-700.

166. Ponomarev ED, Dittel BN. Gamma delta T cells regulate the extent and duration of inflammation in the central nervous system by a Fas ligand-dependent mechanism. J Immunol. 2005; 174(8): 4678-4687.

167. Cairo C, Arabito E, Landi F, et al. Analysis of circulating gammadelta T cells in children affected by IgE-associated and non-IgE-associated allergic atopic eczema/dermatitis syndrome. Clin Exp Immunol. 2005; 141(1): 116-121.

168. Zhang L, Liu J, Wang E, et al. Respiratory syncytial virus protects against the subsequent development of ovalbumin -induced allergicresponses by inhibiting Th2-type $\gamma \delta$ T cells. J Med Virol. 2013; 85(1): 149-156.

169. Svensson L, Lilliehook B, Larsson R, et al. Gamma/delta T cells contribute to the systemic immunoglobulin $\mathrm{E}$ response and local B cell reactivity in allergic eosinophilic airway inflammation. Immunology. 2003; 108:98-108.

170. de Oliveira Henriques MD, Penido C. $\gamma \delta$ T Lymphocytes Coordinate Eosinophil Influx during Allergic Responses. Front Pharmacol. 2012; 3: 200

171. Pawankar R. $\gamma \delta$ T cells in allergic airway diseases. Clin Exp Allergy. 2000; 30: 318-323.

172. Pawankar R, Okuda M, Suzuki K, et al. Phenotypic and molecular characteristics of nasal mucosal $\gamma \delta$ T cells in allergic and infectious rhinitis. Am J Respir Crit Care Med. 1996; 153: 1655-1665.

173. Sicard H, Ingoure S, Luciani B, et al. In vivo immunomanipulation of vgamma9vdelta2 T cells with a synthetic phosphoantigen in a preclinical nonhuman primate model. J Immunol. 2005; 175: 5471-5480.

174. Shojaei H, Oberg H. H, Juricke M, et al. Toll-like receptors 3 and 7 agonists enhance tumor cell lysis by human gammadelta T cells. Cancer Research. 2009; 69: $8710-8717$

175. Gertner-Dardenne J, Bonnafous C, Bezombes C, et al. Bromohydrin pyrophosphate enhances antibody-dependent cell-mediated cytotoxicity induced by therapeutic antibodies. Blood. 2009; 113: 4875-4884.

\section{Author biography}

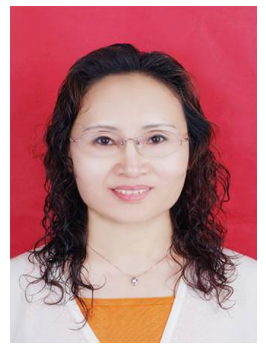

Dr. Yan-Ling $\mathbf{W u}$ is a professor in Molecular Immunology and now heads the Cellular and Molecular Immunology Research Group. She received Master and Doctoral degrees in Applied Life Science in 2003 and in Medicine Science in 2006, respectively, from Tohoku University, Japan. After that, she entered to Professor Minato's group of School of Medicine, Kyoto University, Japan, as a senior researcher working in the field of molecular immunology. Her current research focuses on understanding the molecular mechanisms of gene regulation related to diseases by immune inhibitory receptors. Dr. Wu has published better papers as the first/corresponding author in excellent Journals including Chem \& Biol, ChemBioChem, Int J Biol Sci etc. and given oral presentations in international conferences.

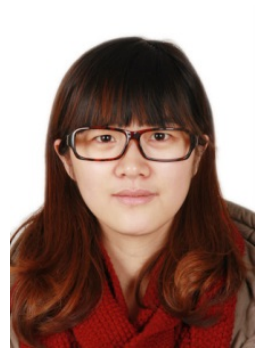

Yan-Ping Ding received her bachelor's degree in biological sciences from Zhejiang University of Chinese Traditional Medicine, China. Since graduation, she has been working in Zhejiang Center of Disease Control and Prevention, China. Her research mainly focuses on the field of Molecular Immunology under the guidance of Prof. Yanling Wu.

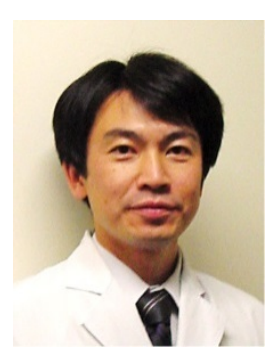

Yoshimasa Tanaka received his Ph. D in Hokkaido University Graduate School of Agriculture with a specialization in Enzymology and Biochemistry. After graduation, he continued his research in the field of Immunobiology. Since 2008, he is an associate professor and works in the Center for Innovation in Immunoregulative Immunology and Therapeutics that belongs to the Kyoto University Graduate School of Medicine.

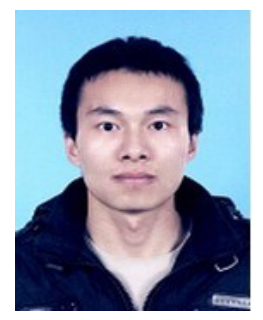

Li-Wen Shen is a postgraduate majoring in pharmacy. He obtained the Bachelor's degree in Biological Engineering in 2012 from Shanxi Datong University, China. After that, he entered Lab of Molecular Immunology, Zhejiang Provincial Center for Disease Control and Prevention, China, working with small molecules to regulate disease-related gene to explore gene-targeted drugs under the direction of Profs Y.-L. Wu and W. Zhang.

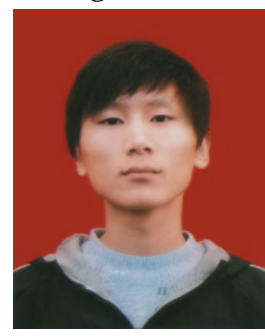

Chuan-He Wei received his Bachelor's degree in 2011 from Jilin Agricultural Science and Technology College, China. Then, he entered Prof. Zhang's group as a postgraduate of College of Pharmaceutical Science, Zhejiang University of Technology, China, his current research mainly focusing on the field of Molecular Immunology under the direction of Profs $W$. Zhang and Y.-L. Wu.

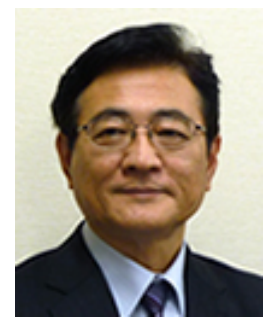

Dr. Nagahiro Minato is a full professor of Department of Immunology and Cell Biology, Graduate School of Medicine, Kyoto University, Japan, since 1992, and since 1998, also a professor of Department of Bio-Regulation, Graduate School of Biostudies, Kyoto University (Joint appointment), Kyoto, Japan. He received his MD \& PhD from Kyoto University in 1975. At present, his research focuses on Immunobiology. Prof Minato has published more than 150 papers in excellent Journals, including Nature Medicine, Nature Cell Biol, Nature Immunol, Nature Med, Proc Natl Acad Sci USA, J Immunol, Blood, J Exp Med etc. 


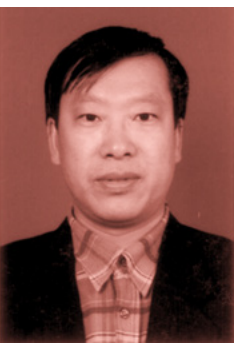

Dr. Wen Zhang is a full professor with 30 years of research and teaching experience in Bioorganic Chemistry and Chemical Biology. Dr. Zhang earned his doctorate degree in Bioorganic Chemistry from East China University of Science and Technology, China. Then, he entered Professor Ohrui's Lab of Tohoku University, Japan, working in the field of molecular recognition as a JSPS postdoctoral fellow. After that, he joined Professor Sugiyama's Chemical Biology group of Kyoto University, Japan, as a COE and JST research fellow working on biology and chemistry of polyamide-nucleic acids interaction. Now, Dr. Zhang has a special interest in elucidating the gene regulation mechanisms with small organic molecules and the development of gene-targeted drug. His group formed in 2008 and established an extremely fruitful collaboration with Prof. Sugiyama's Group in order to better pursue aspects of gene-targeted drug research. To date, Dr. Zhang has published better papers as the first/corresponding author in excellent Journals including JACS, ChemBioChem, Int J Biol Sci etc. 